\title{
Seasonal and diurnal variations in methane and carbon dioxide in the Kathmandu Valley in the foothills of the central Himalayas
}

\author{
Khadak Singh Mahata ${ }^{1,2}$, Arnico Kumar Panday ${ }^{3,4}$, Maheswar Rupakheti ${ }^{1,5}$, Ashish Singh ${ }^{1}$, Manish Naja ${ }^{6}$, and \\ Mark G. Lawrence ${ }^{1,2}$ \\ ${ }^{1}$ Institute for Advanced Sustainability Studies (IASS), Potsdam, Germany \\ ${ }^{2}$ Institute of Earth and Environmental Science, Department of Geo-ecology, University of Potsdam, Potsdam, Germany \\ ${ }^{3}$ International Centre for Integrated Mountain Development (ICIMOD), Lalitpur, Nepal \\ ${ }^{4}$ Department of Environmental Sciences, University of Virginia, Charlottesville, Virginia, USA \\ ${ }^{5}$ Himalayan Sustainability Institute (HIMSI), Kathmandu, Nepal \\ ${ }^{6}$ Aryabhatta Research Institute of Observational Sciences (ARIES), Nainital, India
}

Correspondence to: Maheswar Rupakheti (maheswar.rupakheti@iass-potsdam.de)

Received: 19 December 2016 - Discussion started: 2 March 2017

Revised: 26 July 2017 - Accepted: 12 September 2017 - Published: 24 October 2017

\begin{abstract}
The SusKat-ABC (Sustainable Atmosphere for the Kathmandu Valley-Atmospheric Brown Clouds) international air pollution measurement campaign was carried out from December 2012 to June 2013 in the Kathmandu Valley and surrounding regions in Nepal. The Kathmandu Valley is a bowl-shaped basin with a severe air pollution problem. This paper reports measurements of two major greenhouse gases (GHGs), methane $\left(\mathrm{CH}_{4}\right)$ and carbon dioxide $\left(\mathrm{CO}_{2}\right)$, along with the pollutant $\mathrm{CO}$, that began during the campaign and were extended for 1 year at the SusKat-ABC supersite in Bode, a semi-urban location in the Kathmandu Valley. Simultaneous measurements were also made during 2015 in Bode and a nearby rural site (Chanban) $\sim 25 \mathrm{~km}$ (aerial distance) to the southwest of Bode on the other side of a tall ridge. The ambient mixing ratios of methane $\left(\mathrm{CH}_{4}\right)$, carbon dioxide $\left(\mathrm{CO}_{2}\right)$, water vapor, and carbon monoxide (CO) were measured with a cavity ring-down spectrometer (G2401; Picarro, USA) along with meteorological parameters for 1 year (March 2013-March 2014). These measurements are the first of their kind in the central Himalayan foothills. At Bode, the annual average mixing ratios of $\mathrm{CO}_{2}$ and $\mathrm{CH}_{4}$ were $419.3( \pm 6.0) \mathrm{ppm}$ and $2.192( \pm 0.066) \mathrm{ppm}$, respectively. These values are higher than the levels observed at background sites such as Mauna Loa, USA $\left(\mathrm{CO}_{2}\right.$ : $\left.396.8 \pm 2.0 \mathrm{ppm}, \mathrm{CH}_{4}: 1.831 \pm 0.110 \mathrm{ppm}\right)$ and Waliguan, China $\left(\mathrm{CO}_{2}: 397.7 \pm 3.6 \mathrm{ppm}, \mathrm{CH}_{4}: 1.879 \pm 0.009 \mathrm{ppm}\right)$ during the same period and at other urban and semi-urban
\end{abstract}

sites in the region, such as Ahmedabad and Shadnagar (India). They varied slightly across the seasons at Bode, with seasonal average $\mathrm{CH}_{4}$ mixing ratios of $2.157( \pm 0.230) \mathrm{ppm}$ in the pre-monsoon season, $2.199( \pm 0.241) \mathrm{ppm}$ in the monsoon, $2.210( \pm 0.200) \mathrm{ppm}$ in the post-monsoon, and 2.214 $( \pm 0.209) \mathrm{ppm}$ in the winter season. The average $\mathrm{CO}_{2} \mathrm{mix}-$ ing ratios were $426.2( \pm 25.5) \mathrm{ppm}$ in the pre-monsoon, 413.5 $( \pm 24.2) \mathrm{ppm}$ in the monsoon, $417.3( \pm 23.1) \mathrm{ppm}$ in the postmonsoon, and $421.9( \pm 20.3) \mathrm{ppm}$ in the winter season. The maximum seasonal mean mixing ratio of $\mathrm{CH}_{4}$ in winter was only $0.057 \mathrm{ppm}$ or $2.6 \%$ higher than the seasonal minimum during the pre-monsoon period, while $\mathrm{CO}_{2}$ was $12.8 \mathrm{ppm}$ or $3.1 \%$ higher during the pre-monsoon period (seasonal maximum) than during the monsoon (seasonal minimum). On the other hand, the CO mixing ratio at Bode was $191 \%$ higher during the winter than during the monsoon season. The enhancement in $\mathrm{CO}_{2}$ mixing ratios during the pre-monsoon season is associated with additional $\mathrm{CO}_{2}$ emissions from forest fires and agro-residue burning in northern South Asia in addition to local emissions in the Kathmandu Valley. Published $\mathrm{CO} / \mathrm{CO}_{2}$ ratios of different emission sources in Nepal and India were compared with the observed $\mathrm{CO} / \mathrm{CO}_{2}$ ratios in this study. This comparison suggested that the major sources in the Kathmandu Valley were residential cooking and vehicle exhaust in all seasons except winter. In winter, brick kiln emissions were a major source. Simultaneous measurements in Bode and Chanban (15 July-3 October 
2015) revealed that the mixing ratios of $\mathrm{CO}_{2}, \mathrm{CH}_{4}$, and $\mathrm{CO}$ were $3.8,12$, and $64 \%$ higher in Bode than Chanban. The Kathmandu Valley thus has significant emissions from local sources, which can also be attributed to its bowl-shaped geography that is conducive to pollution build-up. At Bode, all three gas species $\left(\mathrm{CO}_{2}, \mathrm{CH}_{4}\right.$, and $\left.\mathrm{CO}\right)$ showed strong diurnal patterns in their mixing ratios with a pronounced morning peak (ca. 08:00), a dip in the afternoon, and a gradual increase again through the night until the next morning. $\mathrm{CH}_{4}$ and $\mathrm{CO}$ at Chanban, however, did not show any noticeable diurnal variations.

These measurements provide the first insights into the diurnal and seasonal variation in key greenhouse gases and air pollutants and their local and regional sources, which is important information for atmospheric research in the region.

\section{Introduction}

The average atmospheric mixing ratios of two major greenhouse gases (GHGs), $\mathrm{CO}_{2}$ and $\mathrm{CH}_{4}$, have increased by about $40 \%$ (from 278 to $390.5 \mathrm{ppm}$ ) and about $150 \%$ (from 722 to $1803 \mathrm{ppb}$ ), respectively, since preindustrial times $(\sim 1750 \mathrm{AD})$. This is mostly attributed to anthropogenic emissions (IPCC, 2013). The current global annual rate of increase in the atmospheric $\mathrm{CO}_{2}$ mixing ratio is $1-3 \mathrm{ppm}$, with average annual mixing ratios now exceeding a value of $400 \mathrm{ppm}$ at the background reference location in Mauna Loa (WMO, 2016). Between 1750 and 2011, $240( \pm 10) \mathrm{Pg} \mathrm{C}$ of anthropogenic $\mathrm{CO}_{2}$ was accumulated in the atmosphere of which two-thirds were contributed by fossil fuel combustion and cement production, with the remaining coming from deforestation and land use or land cover changes (IPCC, 2013). $\mathrm{CH}_{4}$ is the second largest gaseous contributor to anthropogenic radiative forcing after $\mathrm{CO}_{2}$ (Forster et al., 2007). The major anthropogenic sources of atmospheric $\mathrm{CH}_{4}$ are rice paddies, ruminants, and fossil fuel use, contributing approximately $60 \%$ to the global $\mathrm{CH}_{4}$ budget (Chen and Prinn, 2006; Schneising et al., 2009). The remaining fraction is contributed by biogenic sources such as wetlands and the fermentation of organic matter by microbes in anaerobic conditions (Conrad, 1996).

Increasing atmospheric mixing ratios of $\mathrm{CO}_{2}, \mathrm{CH}_{4}$, and other GHGs and short-lived climate-forcing pollutants (SLCPs) such as black carbon (BC) and tropospheric ozone $\left(\mathrm{O}_{3}\right)$ have caused the global mean surface temperature to increase by $0.85^{\circ} \mathrm{C}$ from 1880 to 2012 . The surface temperature is expected to increase further by up to $2^{\circ}$ at the end of the 21 st century in most representative concentration pathway (RCP) emission scenarios (IPCC, 2013). The increase in surface temperature is linked to the melting of glaciers and ice sheets, sea level rise, extreme weather events, loss of biodiversity, reduced crop productivity, and economic losses (Fowler and Hennessy, 1995; Tan and Shibasaki, 2003).
Seventy percent of global anthropogenic $\mathrm{CO}_{2}$ is emitted in urban areas (Fragkias et al., 2013). Developing countries may have lower per capita GHG emissions than developed countries, but the large cities in developing countries with their high populations and industrial densities are major consumers of fossil fuels and thus emitters of GHGs. South Asia, a highly populated region with rapid growth in urbanization, motorization, and industrialization in recent decades, has an ever-increasing fossil fuel demand. Its combustion emitted $444 \mathrm{Tg} \mathrm{C} \mathrm{yr}^{-1}$ in 2000 (Patra et al., 2013), or about $5 \%$ of the global total $\mathrm{CO}_{2}$ emissions. Furthermore, a major segment of the population in South Asia has an agrarian economy and uses biofuel for cooking activities. Agro-residue burning is also common practice in the region, which is an important major source of air pollutants and greenhouse gases in the region (CBS, 2011; Pandey et al., 2014; Sinha et al., 2014).

The emission and uptake of $\mathrm{CO}_{2}$ and $\mathrm{CH}_{4}$ follow a distinct cycle in South Asia. By using inverse modeling, Patra et al. (2011) found a net $\mathrm{CO}_{2}$ uptake $\left(0.37 \pm 0.20 \mathrm{Pg} \mathrm{C} \mathrm{yr}^{-1}\right)$ during 2008 in South Asia and the uptake (sink) is highest during July-September. The remaining months act as a weak gross sink but a moderate gross source for $\mathrm{CO}_{2}$ in the region. The observed variation is linked with the growing seasons. Agriculture is a major contributor of methane emissions. For instance, in India it contributes to $75 \%$ of $\mathrm{CH}_{4}$ emissions (MoEF, 2007). Ambient $\mathrm{CH}_{4}$ concentrations are highest during June to September (peaking in September) in South Asia, which are also the growing months for rice paddies (Goroshi et al., 2011). The minimum column-averaged $\mathrm{CH}_{4}$ mixing ratios are in February-March (Prasad et al., 2014).

Climate change has impacted South Asia in several ways, as evident in temperature increase, changes in precipitation patterns, higher incidence of extreme weather events (floods, droughts, heat waves, cold waves), melting of snowfields and glaciers in mountain regions, and impacts on ecosystems and livelihoods (ICIMOD, 2009; MoE, 2011). Countries such as Nepal are vulnerable to impacts of climate change due to inadequate preparedness for adaptation to the impacts of climate change (MoE, 2011). Decarbonization of its economy could be an important policy measure in mitigating climate change. The Kathmandu Valley is one of the largest metropolitan areas in the foothills of the Hindu Kush Himalayas, which has a significant reliance on fossil fuels and biofuels. In 2005, fossil fuel burning accounted for $53 \%$ of total energy consumption in the Kathmandu Valley, while biomass and hydroelectricity were 38 and $9 \%$, respectively (Shrestha and Rajbhandari, 2010). Fossil fuel consumed in the Kathmandu Valley accounts for $32 \%$ of the country's fossil fuel imports, and the major fossil fuel consumers are the residential $(53.17 \%)$, transport (20.80\%), industrial $(16.84 \%)$, and commercial $(9.11 \%)$ sectors. The combustion of these fuels in traditional technologies, such as fixed chimney-Bull's trench kilns (FCBTKs) and lowefficiency engines (vehicles, captive power generator sets, etc.), emits significant amounts of greenhouse gases and air 
pollutants. This has contributed to elevated ambient concentrations of particulate matter (PM), including black carbon and organic carbon, and several gaseous species such as ozone, polycyclic aromatic hydrocarbons (PAHs), acetonitrile, benzene, and isocyanic acid (Pudasainee et al., 2006; Aryal et al., 2009; Panday and Prinn, 2009; Sharma et al., 2012; World Bank, 2014; Chen et al., 2015; Putero et al., 2015: Sarkar et al., 2016). The ambient levels often exceed national air quality guidelines (Pudasainee et al., 2006; Aryal et al., 2009; Putero et al., 2015) and are comparable to or higher than ambient levels observed in other major cities in South Asia.

Past studies in the Kathmandu Valley have focused mainly on a few aerosols species (BC, PM) and short-lived gaseous pollutants, such as ozone and carbon monoxide (Pudasainee et al., 2006; Aryal et al., 2009; Panday and Prinn, 2009; Sharma et al., 2012; Putero et al., 2015). To the best of authors' knowledge, no direct measurements of $\mathrm{CO}_{2}$ and $\mathrm{CH}_{4}$ are available for the Kathmandu Valley. Recently, emission estimates of $\mathrm{CO}_{2}$ and $\mathrm{CH}_{4}$ were derived for the Kathmandu Valley using the International Vehicle Emissions (IVE) model (Shrestha et al., 2013). The study estimated $1554 \mathrm{Gg}$ of annual emissions of $\mathrm{CO}_{2}$ from a fleet of vehicles (that consisted of public buses, three-wheelers, taxis, and motorcycles; private cars, trucks, and non-road vehicles were not included in the study) for the year 2010. In addition, the study also estimated $1.261 \mathrm{Gg}$ of $\mathrm{CH}_{4}$ emitted from threewheelers $(10.6 \%)$, taxis $(17.7 \%)$, and motorcycles $(71 \%)$ for 2010.

This study presents the first 12 months of measurements of two key GHGs, $\mathrm{CH}_{4}$ and $\mathrm{CO}_{2}$, along with other trace gases and meteorological parameters in Bode, a semi-urban site in the eastern part of the Kathmandu Valley. The year-long measurement in Bode is part of the SusKat-ABC (Sustainable Atmosphere for the Kathmandu Valley-Atmospheric Brown Clouds) international air pollution measurement campaign conducted in and around the Kathmandu Valley from December 2012 to June 2013. Details of the SusKat-ABC campaign are described in Rupakheti et al. (2017). The present study provides a detailed account of the seasonal and diurnal behavior of $\mathrm{CO}_{2}$ and $\mathrm{CH}_{4}$ and their possible sources. To examine the rural-urban differences and estimate the urban enhancement, these gaseous species were also simultaneously measured for about 3 months (July-October) in 2015 at Chanban, a rural site about $25 \mathrm{~km}$ (aerial distance) outside and southwest of Kathmandu Valley. The seasonality of the trace gases and influence of potential sources in various (wind) directions are further explored via ratio analysis. This measurement provides unique data from a highly polluted but relatively poorly studied region (central Himalayan foothills in South Asia), which could be useful for validation of emissions estimates, model outputs, and satellite observations. The study, which provides new insights on potential sources, can also be a good basis for designing mitigation measures for reducing emissions of air pollutants and con- trolling greenhouse gases in the Kathmandu Valley and the region.

\section{Experiment and methodology}

\subsection{Kathmandu Valley}

The Kathmandu Valley consists of three administrative districts, Kathmandu, Lalitpur, and Bhaktapur, situated between $27.625^{\circ} \mathrm{N}, 27.75^{\circ} \mathrm{N}$ and $85.25^{\circ} \mathrm{E}, 85.375^{\circ} \mathrm{E}$. It is a nearly circular bowl-shaped valley with a valley floor area of approximately $340 \mathrm{~km}^{2}$ located at an altitude of 1300 meters above sea level (ma.s.l.). The surrounding mountains are close to $2000-2800 \mathrm{~m}$ in height above sea level with five mountain passes located at about $200-600 \mathrm{~m}$ above the valley floor and an outlet for the Bagmati River southwest of the Kathmandu Valley. The lack of decentralization in Nepal has resulted in the concentration of economic activities, health and education facilities, the service sector, and most of the central governmental offices in the Kathmandu Valley. Consequently, it is one of the fastest growing metropolitan areas in South Asia with a current population of about 2.5 million and a population growth rate of $4 \%$ per year (World Bank, 2013). Likewise, approximately $50 \%$ of the total vehicle fleet (2.33 million) of the country is in the Kathmandu Valley (DoTM, 2015). The consumption of fossil fuels, such as liquefied petroleum gas (LPG) and kerosene for cooking and heating, dominates residential consumption, while the rest use biofuel (fuel wood, agro-residue, animal dung) for cooking and heating in the Kathmandu Valley. The commercial sector is also growing in the valley, and the latest data indicate the presence of 633 industries of various sizes. These are mainly associated with dyeing, brick kilns, and manufacturing industries. Fossil fuels, such as coal and biofuels, are the major fuels used in brick kilns. Brick kilns are reported as one of the major contributors of air pollution in the Kathmandu Valley (Chen et al., 2015; Kim et al., 2015; Sarkar et al., 2016). There are about 115 brick industries in the valley (personal communication with Mahendra Chitrakar, President of the Federation of Nepalese Brick Industries). Acute power shortage in the valley is common all year, especially in the dry season (winter and the pre-monsoon) when the power cuts can last up to $12 \mathrm{~h}$ a day (NEA, 2014). Energy demand during the power cut period is met with the use of small (67\% of 776 generators surveyed for the World Bank study had a capacity less than $50 \mathrm{kVA}$ ) but numerous captive power generators (diesel or petrol), which further contribute to the valley's poor air quality. According to the World Bank estimate, over 250000 such generator sets are used in the Kathmandu Valley alone, producing nearly $200 \mathrm{MW}$ of captive power and providing about $28 \%$ of the total electricity consumption of the valley (World Bank, 2014). Apart from these sources, trash burning, which is a common prac- 
tice (more prevalent in winter) throughout the valley, is one of the major sources of air pollutants and GHGs.

Climatologically, the Kathmandu Valley is subtropical with an annual mean temperature of $18^{\circ} \mathrm{C}$ and annual average rainfall of $1400 \mathrm{~mm}, 90 \%$ of which occurs in the monsoon season (June-September). The rest of the year is dry with some sporadic rain events. The wind circulation at a large scale in the region is governed by the Asian monsoon circulation, and hence the seasons are also classified based on such large-scale circulations and precipitation: pre-monsoon (March-May), monsoon (June-September), post-monsoon (October-November), and winter (DecemberFebruary). Sharma et al. (2012) used the same classification of seasons while explaining the seasonal variation of $\mathrm{BC}$ concentrations observed in the Kathmandu Valley. Locally in the valley, the mountain-valley wind circulations play an important role in influencing air quality. The wind speed at the valley floor is calm $\left(\leq 1 \mathrm{~m} \mathrm{~s}^{-1}\right)$ in the morning and night, while a westerly wind develops after 11:00 in the morning until dusk and switches to a mild easterly at night (Panday and Prinn, 2009; Regmi et al., 2003). This is highly conducive to building up air pollution in the valley, which becomes worse during the dry season.

\subsection{Study sites}

Two sites, a semi-urban site within the Kathmandu Valley and a rural site outside the Kathmandu Valley, were selected for this study. The details of the measurements carried out at these sites are described in Table 1 and Sects. 2.2.1 and 2.2.2.

\subsubsection{Bode (SusKat-ABC supersite)}

The SusKat-ABC supersite was set up at Bode, a semi-urban location (Fig. 1) in the Madhyapur Thimi municipality in the Bhaktapur district on the eastern side of the Kathmandu Valley. The site is located at $27.68^{\circ} \mathrm{N}, 85.38^{\circ} \mathrm{E}$ and $1344 \mathrm{~m}$ a.s.l. The local area around the site has a number of scattered houses and agricultural fields. The agricultural fields are used for growing rice paddies in the monsoon season. The site also receives an outflow of polluted air from three major cities in the valley: Kathmandu metropolitan city and Lalitpur submetropolitan city, both mainly during daytime, and Bhaktapur sub-metropolitan city mainly during nighttime. Among other local sources around the site, about 10 brick kilns are located in the east and southeast direction within approximately $1-4 \mathrm{~km}$ of the site, which are operational only during the dry season (January to April). There are close to 20 small and medium industries (pharmaceuticals, plastics, electronics, tin, wood, aluminum, iron, fabrics, etc.) scattered in the same direction. Tribhuvan International Airport (TIA) is located approximately $4 \mathrm{~km}$ to the west of Bode.

\subsubsection{Chanban}

Chanban is a rural background site in the Makawanpur district outside of the Kathmandu Valley (Fig. 1). This site is located $\sim 25 \mathrm{~km}$ of aerial distance southwest from Bode. The site is located on a small ridge $\left(27.65^{\circ} \mathrm{N}\right.$, $85.14^{\circ} \mathrm{E} ; 1896 \mathrm{~m}$ a.s.l.) between two villages, Chitlang and Bajrabarahi, within the forested watershed area of the Kulekhani reservoir, which is located approximately $4.5 \mathrm{~km}$ southwest of the site. The instruments were set up on the roof of a one-storey building in an open space inside the Nepalese Army barracks. There was a kitchen at the barracks about $100 \mathrm{~m}$ to the southeast of the measurement site. The kitchen uses LPG, electricity, kerosene, and firewood for cooking activities.

\subsection{Instrumentation}

The measurements were carried out in two phases in 20132014 and 2015. In phase one, a cavity ring-down spectrometer (G2401; Picarro, USA) was deployed in Bode to measure ambient $\mathrm{CO}_{2}, \mathrm{CH}_{4}, \mathrm{CO}$, and water vapor mixing ratios. Twelve months (6 March 2013 to 5 March 2014) of continuous measurements were made in Bode. The operational details of the instruments deployed in Bode are also provided in Table 1. In phase two, simultaneous measurements were made in Bode and Chanban for a little less than 3 months (15 July to 3 October 2015).

The Picarro G2401 analyzer quantifies spectral features of gas-phase molecules by using a novel wavelength-scanned cavity ring-down spectroscopic technique (CRDS). The instrument has a $30 \mathrm{~km}$ path length in a compact cavity that results in high sensitivity. Because of the high-precision wavelength monitor, it uses absolute spectral position and maintains accurate peak quantification. Further, it only monitors the special features of interest to reduce drift. The instrument also has water correction to report the dry gas fraction. The reported measurement precisions for $\mathrm{CO}_{2}, \mathrm{CH}_{4}, \mathrm{CO}$, and water vapor in dry gas are $<150,<30,<1$, and $<200$ ppm for $5 \mathrm{~s}$ with 1 standard deviation (Picarro, 2015).

In Bode, the Picarro analyzer was placed on the fourth floor of a five-storey building with an inlet $0.5 \mathrm{~m}$ above the roof of the building with a $360^{\circ}$ view (total inlet height: $20 \mathrm{~m}$ above the ground). The sample air was filtered at the inlet to keep dust and insects out and was drawn into the instrument through a $9 \mathrm{~m}$ Teflon tube (1/4 inch ID). The Picarro analyzer was set to record data every $5 \mathrm{~s}$ and recorded both directly sampled data and water-corrected data for $\mathrm{CO}_{2}$ and $\mathrm{CH}_{4}$. In this paper, only water-corrected or dry mixing ratios of $\mathrm{CH}_{4}$ and $\mathrm{CO}_{2}$ were used to calculate the hourly averages for diurnal and seasonal analysis.

The instruments were factory calibrated before commencing the field measurements. The Picarro G2401 model is designed for remote application and long-term deployment with minimal drift and less requirement for intensive cali- 
Table 1. Instruments and sampling at Bode (semi-urban site) and Chanban (rural site).

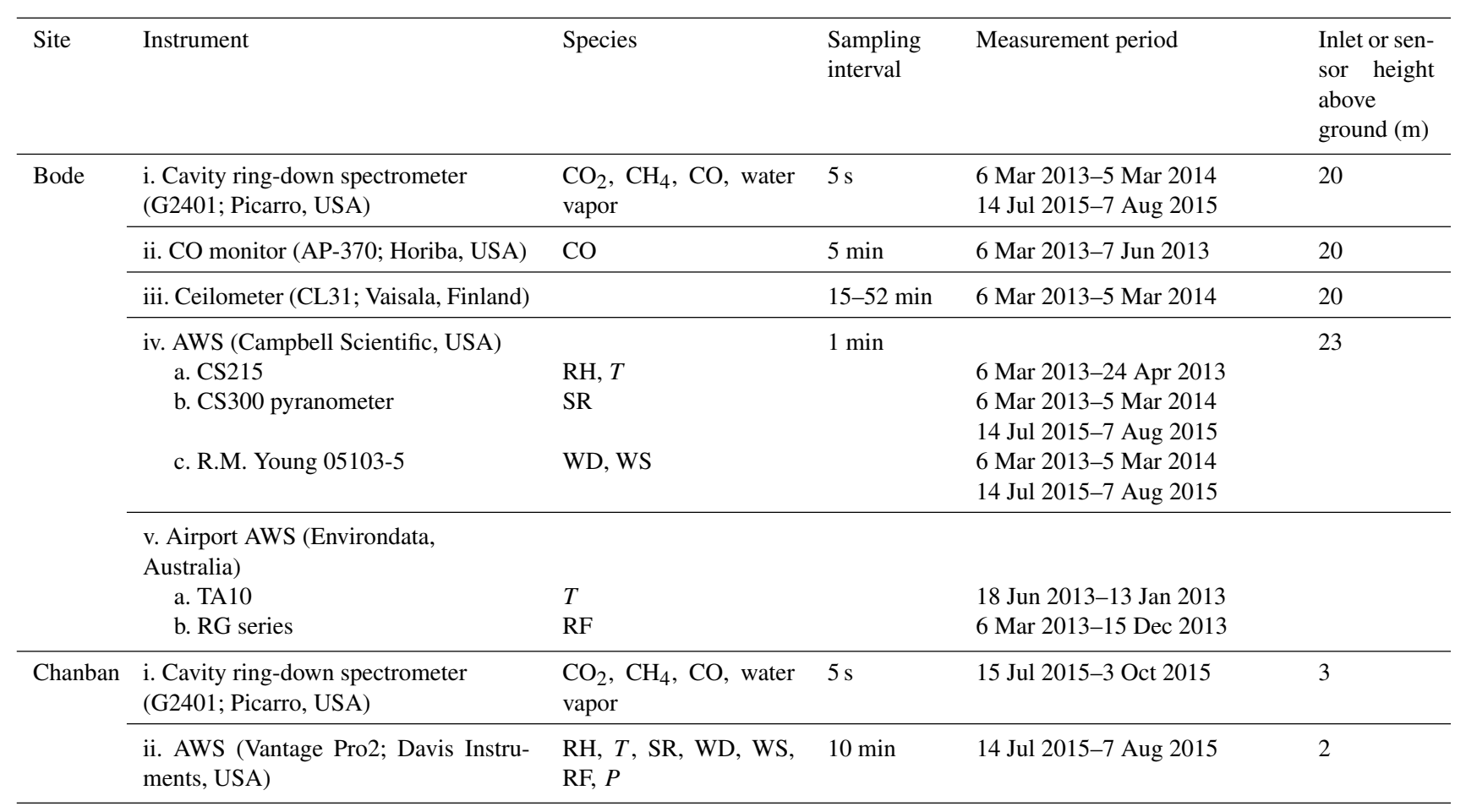

AWS: automatic weather station, RH: ambient relative humidity, $T$ : ambient temperature, SR: global solar radiation, WS: wind speed, WD: wind direction, RF: rainfall, $P$ : ambient pressure.

bration (Crosson, 2008). It was thus chosen for the current study in places like Kathmandu where there is limited to no availability of high-quality reference gases. Regular calibration of the Picarro G2401 in the field during the 2013-2014 deployment was not conducted due to challenges associated with the quality of the reference gas, especially for $\mathrm{CO}$ and $\mathrm{CH}_{4}$. One-time calibration was performed for $\mathrm{CO}_{2}$ (at 395 and $895 \mathrm{ppm}$ ) in July 2015 before commencing the simultaneous measurements in Bode and Chanban in 2015. The difference between the $\mathrm{CO}_{2}$ mixing ratio reported by the analyzer and the reference mixing ratio was within $5 \%$. CO observations from the Picarro G2401 were compared with observations from another $\mathrm{CO}$ analyzer (Horiba, model AP370) that was also operated in Bode for 3 months (March-May 2013). The Horiba CO monitor was a new unit, which was factory calibrated before its first deployment in Bode. Nevertheless, this instrument was intercompared with another $\mathrm{CO}$ analyzer (same model) from the same manufacturer prior to the campaign, and its correlation coefficient was 0.9 (slope of data from the new unit ( $y$ axis) vs. the old unit ( $x$ axis) $=$ 1.09). Primary gas cylinders from Linde UK (1150 ppb) and secondary gases from Ultra-Pure Gases and Chemtron Science Laboratories ( $1790 \mathrm{ppb}$ ) were used for the calibration of the $\mathrm{CO}$ instrument. Further details on $\mathrm{CO}$ measurements and the calibration of the Horiba AP370 can be found in Sarangi et al. (2014, 2016). A statistically significant correlation $(r=0.99$, slope $=0.96)$ was found between the Picarro and Horiba hourly average $\mathrm{CO}$ mixing ratio data (Supplement Fig. S1). Furthermore, the monthly mean differences between these two instruments (Horiba AP370 minus Picarro G2401) were calculated to be $0.02 \mathrm{ppm}(3 \%), 0.04 \mathrm{ppm}$ $(5 \%)$, and $0.02 \mathrm{ppm}(4 \%)$ in March, April, and May, respectively. For the comparison period of 3 months, the mean difference was $0.02 \mathrm{ppm}(4 \%)$. Overall differences were small to negligible during the comparison period, and thus adjustment in the data was deemed unnecessary.

In addition to being highly selective to individual species, the Picarro G2401 has a water correction function and thus accounts for the any likely drift in $\mathrm{CO}, \mathrm{CO}_{2}$, and $\mathrm{CH}_{4}$ mixing ratios with the fluctuating water vapor concentration (Chen et al., 2013; Crosson, 2008). Crosson (2008) also estimated a peak to peak drift of $0.25 \mathrm{ppm}$. Further, Crosson (2008) observed a $1.2 \mathrm{ppb} d a y^{-1}$ drift in $\mathrm{CO}_{2}$ after 170 days from the initial calibration. For a duration of 1 year the drift will be less than $1 \mathrm{ppm}$, which is less than $1 \%$ of the observed mixing ratio in Bode (hourly ranges: 376-537 ppm) even if the drift was of same magnitude as in the case of Crosson (2008). Crosson (2008) reported a 0.8 ppb peak-to-peak drift in $\mathrm{CH}_{4}$ measurements for 18 days after the initial calibration.

There were other instruments concurrently operated in Bode: a ceilometer for measuring mixing-layer height (CL31; Vaisala, Finland) and an automatic weather station (AWS; Campbell Scientific, USA). The ceilometer was installed on the rooftop ( $20 \mathrm{~m}$ above the ground) of the build- 


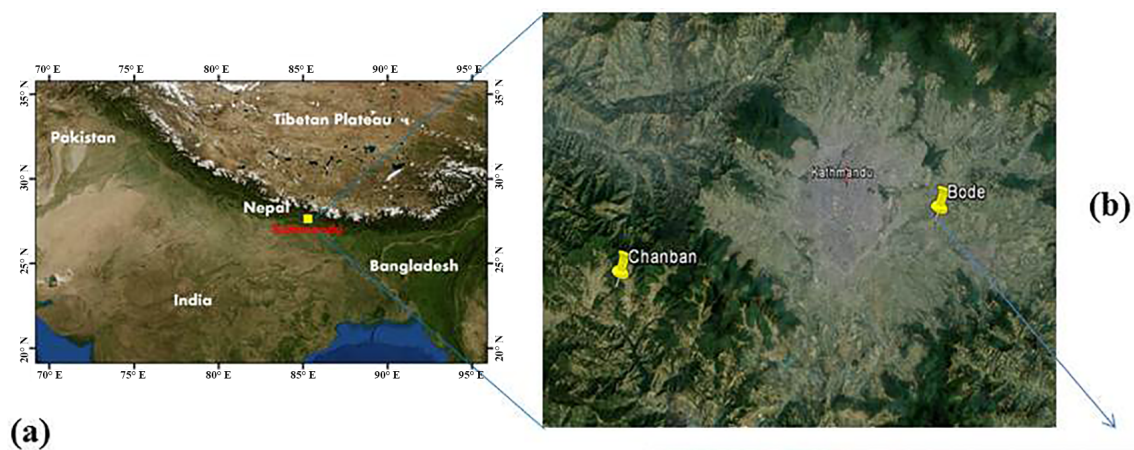

(a)

(c)

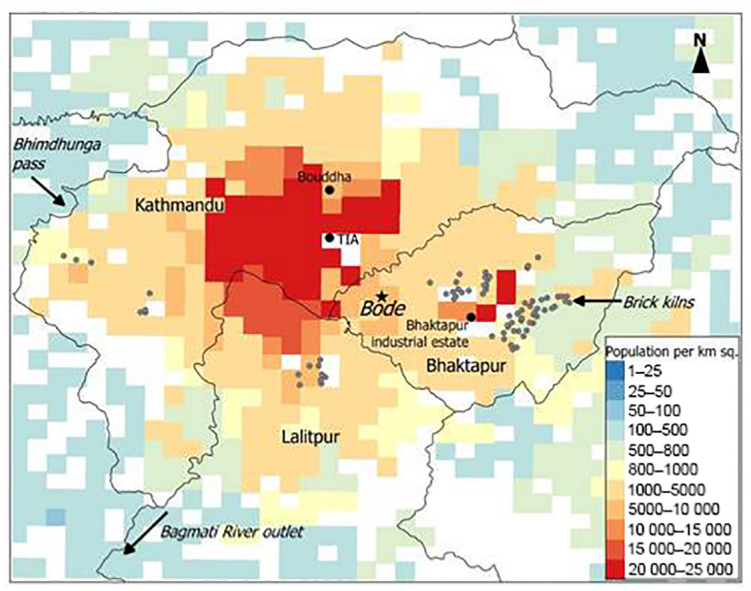

Figure 1. Location of measurement sites: (a) Kathmandu Valley (b) semi-urban measurement site at Bode in the Kathmandu Valley and a rural measurement site at Chanban in the Makawanpur district, Nepal; (c) the general setting of the Bode site. The colored grid and TIA represent population density and the Tribhuvan International Airport, respectively.

ing (Mues et al., 2017). For measuring the meteorological parameters, a Campbell Scientific AWS (USA) was set up on the roof of the building with sensors mounted at $2.9 \mathrm{~m}$ above the surface of the roof ( $22.9 \mathrm{~m}$ from the ground). The Campbell Scientific AWS measured wind speed and direction, temperature, relative humidity, and solar radiation every minute. Temperature and rainfall data were taken from an AWS operated by the Department of Hydrology and Meteorology (DHM), Nepal at Tribhuvan International Airport (TIA; see Fig. 1) $\sim 4 \mathrm{~km}$ west of the Bode site.

At Chanban, the inlet for the Picarro gas analyzer was kept on the rooftop $\sim 3 \mathrm{~m}$ above the ground and the sample air was drawn through a $3 \mathrm{~m}$ long Teflon tube ( $1 / 4 \mathrm{inch}$ ID). The sample was filtered at the inlet $(5-6 \mu \mathrm{m}$ pore size) to prevent aerosol particles from entering into the analyzer. An AWS (Vantage Pro2; Davis, USA) was also set up in an open area about $17 \mathrm{~m}$ away from the building with the sensors mounted at $2 \mathrm{~m}$ above the ground.

\section{Results and discussion}

The results and discussion are organized as follow: Sect. 3.1 describes year-round variation in $\mathrm{CH}_{4}, \mathrm{CO}_{2}, \mathrm{CO}$, and water vapor at Bode; Sects. 3.2 and 3.3 present the analysis of the observed monthly, seasonal, and diurnal variations. Sections 3.4 and 3.5 discuss the interrelation of $\mathrm{CO}_{2}, \mathrm{CH}_{4}$, and $\mathrm{CO}$ and potential emission sources in the valley, and Sect. 3.6 compares and contrasts $\mathrm{CH}_{4}, \mathrm{CO}_{2}$, and $\mathrm{CO}$ at Bode and Chanban.

\subsection{Time series of $\mathrm{CH}_{4}, \mathrm{CO}_{2}, \mathrm{CO}$, and water vapor mixing ratios}

Figure 2 shows the time series of hourly mixing ratios of $\mathrm{CH}_{4}, \mathrm{CO}_{2}, \mathrm{CO}$, and water vapor at Bode. Meteorological data from Bode and Tribhuvan International Airport are also shown in Fig. 2. Data gaps in Fig. 2a and b were due to maintenance of the measurement station. In general, the fluctuations in the mixing ratio for $\mathrm{CO}$ were higher (in terms of $\%$ change) than in $\mathrm{CH}_{4}$ and $\mathrm{CO}_{2}$ during the sampling period. CO mixing ratios decreased and water vapor mixing ratios increased significantly during the rainy season (JuneSeptember). For the entire sampling period, the annual averages ( \pm 1 standard deviation) of $\mathrm{CH}_{4}, \mathrm{CO}_{2}, \mathrm{CO}$, and water vapor mixing ratios were $2.192( \pm 0.066) \mathrm{ppm}, 419.3$ $( \pm 6.0) \mathrm{ppm}, 0.50( \pm 0.23) \mathrm{ppm}$, and $1.73( \pm 0.66) \%$, respectively. The relative standard deviations (RSDs) for the annual average of $\mathrm{CH}_{4}, \mathrm{CO}_{2}$, and $\mathrm{CO}$ were thus 3, 1.4 , and $46 \%$, respectively. The RSDs at Mauna Loa were $\mathrm{CH}_{4} 6 \%$ and 

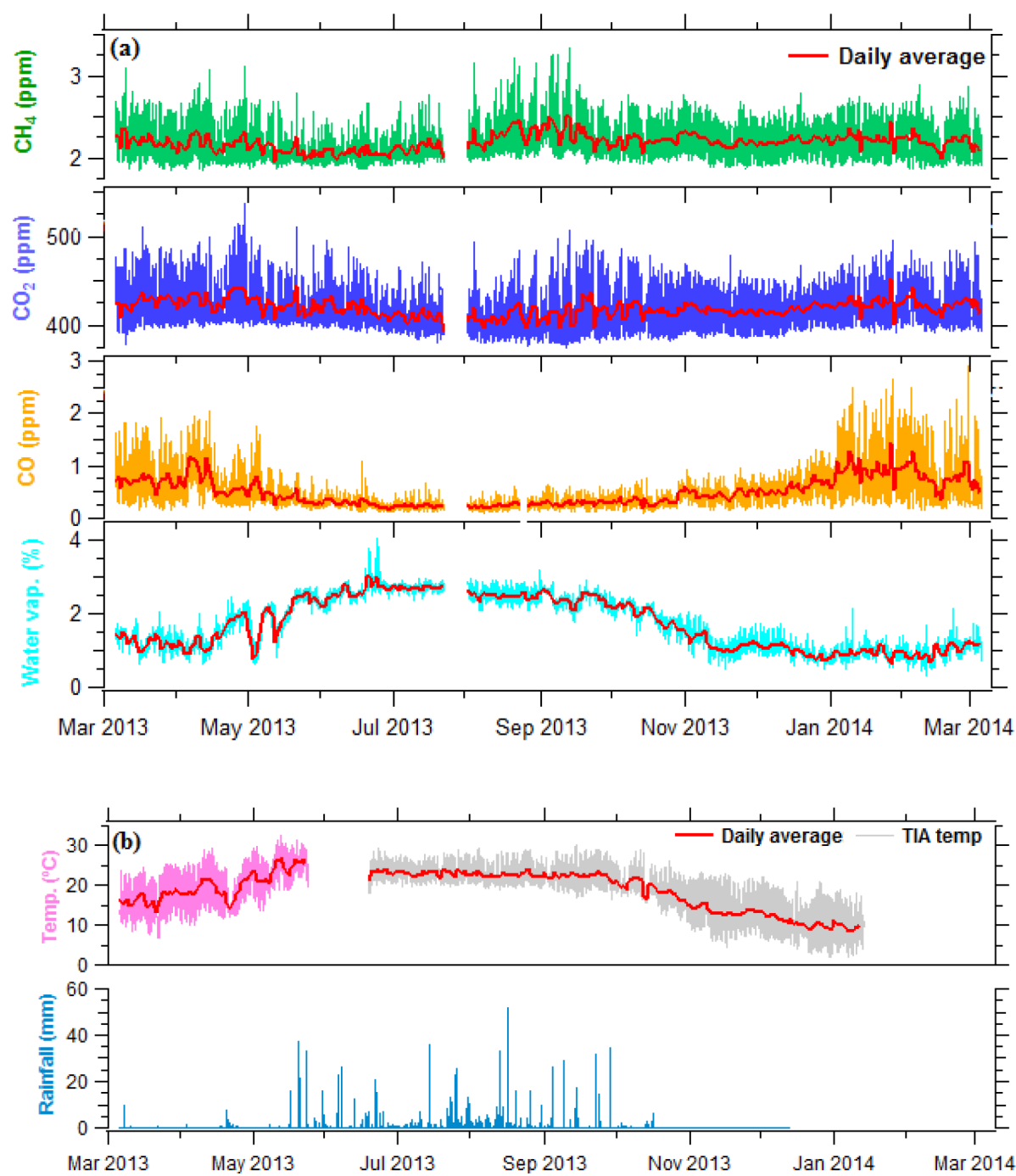

Figure 2. Time series of hourly average (a) mixing ratios of $\mathrm{CH}_{4}, \mathrm{CO}_{2}, \mathrm{CO}$, and water vapor measured with a cavity ring-down spectrometer (Picarro G2401) at Bode. (b) Temperature and rainfall monitored at Tribhuvan International Airport (TIA) $\sim 4 \mathrm{~km}$ to the west of the Bode site in the Kathmandu Valley, Nepal. The temperature shown in pink is observed at the Bode site.

$\mathrm{CO}_{2} 0.5 \%$. At Waliguan they were $\mathrm{CH}_{4} 0.48 \%$ and $\mathrm{CO}_{2}$ $0.9 \%$. The high variability in the annual mean, notably for $\mathrm{CO}$ in Bode, could be indicative of the seasonality of emission sources and meteorology. The annual $\mathrm{CH}_{4}$ and $\mathrm{CO}_{2}$ mixing ratios were compared to the historical background site (Mauna Loa Observatory, Hawaii, USA) and the background site (Waliguan, China) in Asia, which will provide insight on spatial differences. The selection of neighboring urban and semi-urban sites, where many emission sources are typical for the region, for comparison provides information on relative differences (higher or lower), which will help in investigating possible local emission sources in the valley. As expected, the annual means of $\mathrm{CH}_{4}$ and $\mathrm{CO}_{2}$ mixing ratios in the Kathmandu Valley were higher than the levels observed at background sites in the region and elsewhere (Table 4). We performed a significance test at a $95 \%$ confidence level ( $t$ test) for the annual mean values between the sites to evaluate whether the observed difference is statistically significant $(p<0.05)$, which was confirmed for the annual mean $\mathrm{CH}_{4}$ and $\mathrm{CO}_{2}$ between Bode and Mauna Loa and between Bode and Waliguan. $\mathrm{CH}_{4}$ was nearly $20 \%$ higher at Bode than at the Mauna Loa Observatory $(1.831 \pm 0.110 \mathrm{ppm})$ (Dlugokencky et al., 2017) and calculated (ca.) $17 \%$ higher than at Mt. Waliguan $(1.879 \pm 0.009 \mathrm{ppm})$ for the same observation period (Dlugokencky et al., 2016a). The slightly higher $\mathrm{CH}_{4}$ mixing ratios between Bode and Waliguan than at the Mauna Loa Observatory could be due to rice farming as a key source of $\mathrm{CH}_{4}$ in this part of Asia. Thus, it could be associated with such agricultural activities in this region. Similarly, the annual average $\mathrm{CH}_{4}$ at Bode during 2013-2014 was found comparable to an urban site in Ahmedabad (1.880 \pm 0.4 ppm, i.e., RSD: $21.3 \%)$ in India for 
2002 (Sahu and Lal, 2006) and 14\% higher than in Shadnagar ( $1.92 \pm 0.07 \mathrm{ppm}$, i.e., RSD: $3.6 \%$ ), a semi-urban site in Telangana state $(\sim 70 \mathrm{~km}$ north from Hyderabad) during 2014 (Sreenivas et al., 2016). Likewise, the difference between annual mean mixing ratios at Bode $(419.3 \pm 6.0 \mathrm{ppm}$, $1.4 \%$ RSD) vs. Mauna Loa $(396.8 \pm 2.0 \mathrm{ppm}, 0.5 \% \mathrm{RSD})$ and Bode vs. Waliguan $(397.7 \pm 3.6 \mathrm{ppm}, 0.9 \%$ variability; Dlugokencky et al., 2016b) was statistically significant $(p<0.05)$.

The high $\mathrm{CH}_{4}$ and $\mathrm{CO}_{2}$ mixing ratios at Bode in comparison to Ahmedabad and Shadnagar could be due to more than 115 coal-biomass-fired brick kilns, some of which are located near the site (less than $4 \mathrm{~km}$ ), and the confinement of pollutants within the valley due to the bowl-shaped topography of the Kathmandu Valley. Although Ahmedabad is a big city with a population larger than the Kathmandu Valley, the measurement site is far from the nearby heavy polluting industries and situated on plains where the ventilation of pollutants would be more efficient as opposed to the Kathmandu Valley. The major polluting sources were industries, residential cooking, and the transport sector in Ahmedabad (Chandra et al., 2016). Shadnagar is a small town with a population of 0.16 million, and major sources were industries (small to medium) and biomass burning in residential cooking (Sreenivas et al., 2016).

The monthly average $\mathrm{CO}_{2}$ mixing ratios in 2015 in Chanban (August: 403.4, September: $399.1 \mathrm{ppm}$ ) were slightly higher than the background sites at the Mauna Loa Observatory (August: 398.89 ppm, September: $397.63 \mathrm{ppm}$; NOAA, 2015) and Mt. Waliguan (August: $394.55 \mathrm{ppm}$, September: $397.68 \mathrm{ppm}$; Dlugokencky et al., 2016b). For these two months in 2015, $\mathrm{CH}_{4}$ mixing ratios were also higher in Bode (August: $2.281 \mathrm{ppm}$, September: $2.371 \mathrm{ppm}$ ) and Chanban (August: $2.050 \mathrm{ppm}$, September: $2.102 \mathrm{ppm}$ ) compared to the Mauna Loa Observatory (August: $1.831 \mathrm{ppm}$, September: 1.846 ppm; Dlugokencky et al., 2017) and Mt. Waliguan (August: $1.915 \mathrm{ppm}, 1.911 \mathrm{ppm}$; Dlugokencky et al., 2016a). The small differences in $\mathrm{CO}_{2}$ between Chanban and the background sites mentioned above indicate fewer and/or less intense $\mathrm{CO}_{2}$ sources at Chanban during these months because of the lack of burning activities due to rainfall in the region. The garbage and agro-residue burning activities were also absent or reduced around Bode during the monsoon period. However, high $\mathrm{CH}_{4}$ values in August and September in Bode, Chanban, and Mt. Waliguan in comparison to the Mauna Loa Observatory may indicate the influence of $\mathrm{CH}_{4}$ emissions from paddy fields in the Asian region.

\subsection{Monthly and seasonal variations}

Figure 3 shows the monthly box plot of hourly $\mathrm{CH}_{4}, \mathrm{CO}_{2}$, $\mathrm{CO}$, and water vapor observed for 1 year in Bode. Monthly and seasonal averages of $\mathrm{CH}_{4}$ and $\mathrm{CO}_{2}$ mixing ratios at Bode are summarized in Tables 2 and 3. $\mathrm{CH}_{4}$ levels were lowest during May-July (ranges from 2.093-2.129 ppm) and high- est during August-September (2.274-2.301 ppm) followed by winter. In addition to the influence of active local sources, the shallow boundary layer in winter was linked to elevated concentrations (Panday and Prinn, 2009; Putero et al., 2015; Mues et al., 2017). The low $\mathrm{CH}_{4}$ values from May to July may be associated with the absence of brick kilns and frequent rainfall in these months. Brick kilns were operational during January to April. Rainfall also leads to the suppression of open burning activities in the valley (see Fig. 2b). $\mathrm{CH}_{4}$ was slightly higher (statistically significant, $p<0.05$ ) in the monsoon season (July-September) than in the pre-monsoon season (unlike $\mathrm{CO}_{2}$, which was higher in the pre-monsoon) and could be associated with the addition of $\mathrm{CH}_{4}$ flux from the waterlogged rice paddies (Goroshi et al., 2011). There was a visible drop in $\mathrm{CH}_{4}$ from September to October, but it remained consistently over $2.183 \mathrm{ppm}$ from October to April with little variation between these months. Rice-growing activities are minimal or absent in October and beyond and thus may be related to the observed dip in the $\mathrm{CH}_{4}$ mixing ratio.

Comparison of seasonal average $\mathrm{CH}_{4}$ mixing ratios at Bode and Shadnagar (a semi-urban site in India) indicated that $\mathrm{CH}_{4}$ mixing ratios at Bode were higher in all seasons than at Shadnagar: pre-monsoon $(1.89 \pm 0.05 \mathrm{ppm})$, monsoon $(1.85 \pm 0.03 \mathrm{ppm})$, post-monsoon $(2.02 \pm 0.01 \mathrm{ppm})$, and winter $(1.93 \pm 0.05 \mathrm{ppm}$; Sreenivas et al., 2016). The possible reason for lower $\mathrm{CH}_{4}$ at Shadnagar in all seasons could be associated with geographical location and difference in local emission sources. The highest $\mathrm{CH}_{4}$ mixing ratio in Shadnagar was reported in the post-monsoon, which was associated with harvesting in the kharif season (JulyOctober), while the minimum was in the monsoon. Shadnagar is a relatively small city (population $\sim 0.16$ million) compared to the Kathmandu Valley, and the major local sources that may have an influence on $\mathrm{CH}_{4}$ emissions include biofuel, agro-residue burning, and residential cooking.

The seasonal variation in $\mathrm{CO}_{2}$ could be due to (i) the seasonality of major emission sources, such as brick kilns, (ii) the seasonal growth of vegetation $\left(\mathrm{CO}_{2}\right.$ sink; Patra et al., 2011), and (iii) atmospheric transport associated with regional synoptic atmospheric circulation (monsoon circulation and westerly disturbance in the spring season), which could transport regional emission sources from vegetation fires and agricultural residue burning (Putero et al., 2015), and a local mountain-valley circulation effect (Kitada and Regmi, 2003; Panday et al., 2009). The concentrations of most pollutants in the region are lower during the monsoon period (Sharma et al., 2012, Marinoni, 2013; Putero et al., 2015) because frequent and heavy rainfall suppresses emission sources. We saw a drop in the $\mathrm{CO}_{2}$ mixing ratio during the rainfall period due to changes in various processes, such as enhanced vertical mixing, uptake of $\mathrm{CO}_{2}$ by vegetation and soils, and, where relevant, reduction in combustion sources. $\mathrm{CO}_{2}$ can also dissolve into rainfall, forming carbonic acid, which may lead to a small decrease in the $\mathrm{CO}_{2}$ mixing ratio as has been observed during high-intensity rain- 

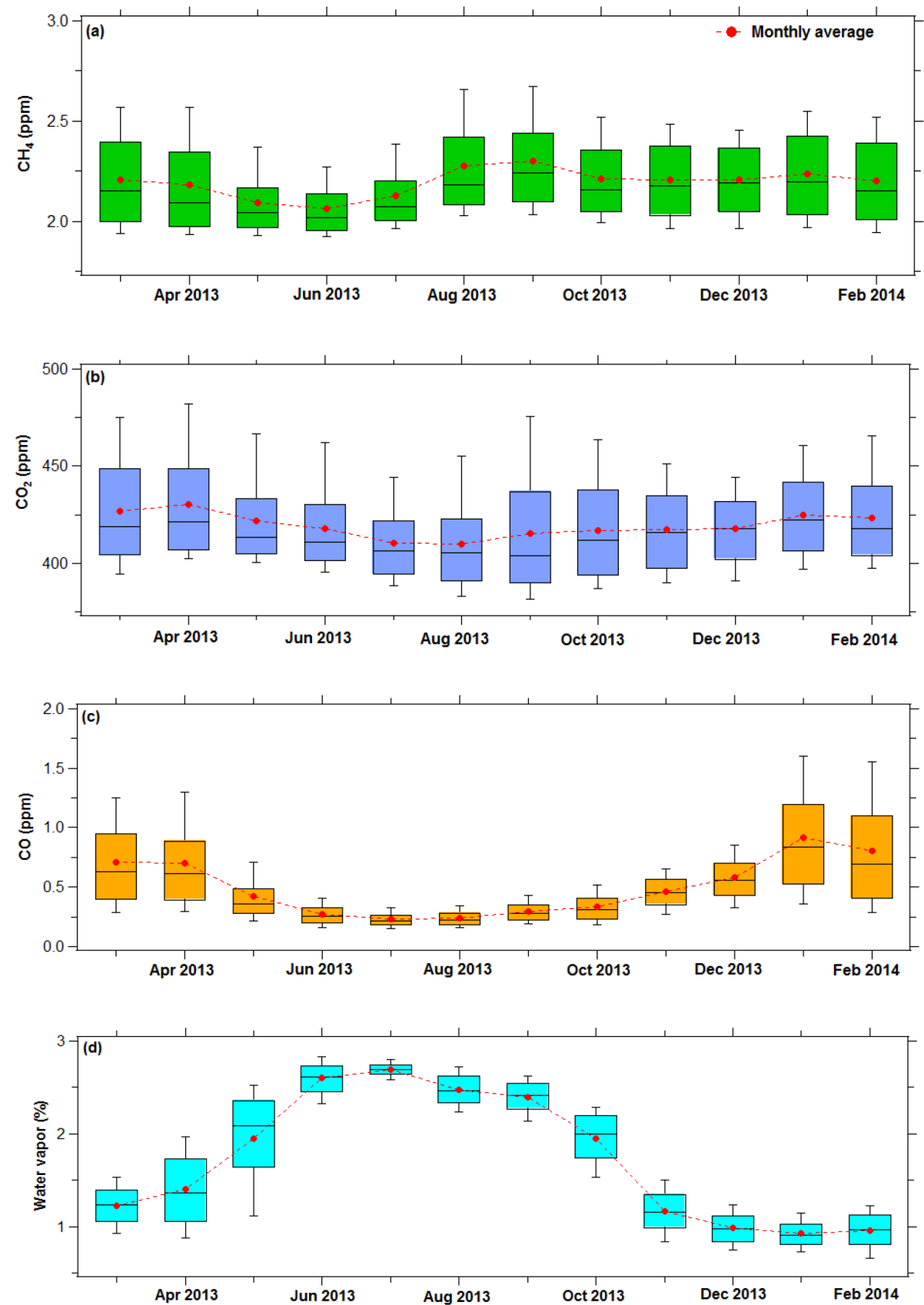

Figure 3. Monthly variations in the mixing ratios of hourly (a) $\mathrm{CH}_{4}$, (b) $\mathrm{CO}_{2}$, (c) $\mathrm{CO}$, and (d) water vapor observed at a semi-urban site (Bode) in the Kathmandu Valley over a period of 1 year. The lower ends and upper ends of the whisker represent the 10th and 90th percentiles, respectively; the lower end and upper end of each box represents the 25 th and 75 th percentile, respectively, and the black horizontal line in the middle of each box is the median for each month, while the red dot represents the mean for each month.

fall (Chaudhari et al., 2007; Mahesh et al., 2014). The monsoon is also the growing season with higher $\mathrm{CO}_{2}$ assimilation by plants than in other seasons (Sreenivas et al., 2016). In contrast, the winter, pre-monsoon, and post-monsoon seasons experience an increase in emission activities in the Kathmandu Valley (Putero et al., 2015).
The $\mathrm{CO}_{2}$ mixing ratios were in the range of $376-537 \mathrm{ppm}$ for the entire observation period. Differences with $\mathrm{CH}_{4}$ were observed in September and October when $\mathrm{CO}_{2}$ was increasing (mean and median) in contrast to $\mathrm{CH}_{4}$, which showed the opposite trend. The observed increase in $\mathrm{CO}_{2}$ after October may be related to little or no rainfall, which results in the absence of rain washout and/or no suppression of active emis- 
Table 2. Summary of monthly average $\mathrm{CH}_{4}$ and $\mathrm{CO}_{2}$ mixing ratios observed at Bode, a semi-urban site in the Kathmandu Valley, from March 2013 to February 2014 (mean, standard deviation (SD), median, minimum (min.), maximum (max.), and number of data points of hourly average values).

\begin{tabular}{|c|c|c|c|c|c|c|c|c|c|c|c|}
\hline \multirow[t]{2}{*}{ Month } & \multicolumn{5}{|c|}{$\mathrm{CH}_{4}(\mathrm{ppm})$} & \multicolumn{5}{|c|}{$\mathrm{CO}_{2}(\mathrm{ppm})$} & \multirow[t]{2}{*}{ Data points } \\
\hline & Mean & SD & Median & Min. & Max. & Mean & SD & Median & Min. & Max. & \\
\hline Mar & 2.207 & 0.245 & 2.152 & 1.851 & 3.094 & 426.6 & 26.4 & 418.3 & 378.8 & 510.8 & 596 \\
\hline Apr & 2.183 & 0.252 & 2.094 & 1.848 & 3.121 & 430.3 & 27.4 & 421.0 & 397.0 & 536.9 & 713 \\
\hline May & 2.093 & 0.174 & 2.040 & 1.863 & 2.788 & 421.7 & 22.1 & 413.4 & 395.9 & 511.2 & 725 \\
\hline Jun & 2.061 & 0.142 & 2.017 & 1.869 & 2.675 & 417.9 & 21.3 & 410.4 & 390.5 & 495.7 & 711 \\
\hline Jul & 2.129 & 0.168 & 2.074 & 1.893 & 2.770 & 410.3 & 18.2 & 406.3 & 381.0 & 471.0 & 500 \\
\hline Aug & 2.274 & 0.260 & 2.181 & 1.953 & 3.219 & 409.9 & 22.8 & 405.3 & 376.1 & 493.1 & 737 \\
\hline Sep & 2.301 & 0.261 & 2.242 & 1.941 & 3.331 & 414.9 & 30.2 & 404.0 & 375.9 & 506.2 & 710 \\
\hline Oct & 2.210 & 0.195 & 2.156 & 1.927 & 2.762 & 417.0 & 25.1 & 411.8 & 381.9 & 486.7 & 743 \\
\hline Nov & 2.207 & 0.203 & 2.178 & 1.879 & 2.705 & 417.2 & 20.7 & 415.7 & 385.7 & 478.9 & 717 \\
\hline Dec & 2.206 & 0.184 & 2.193 & 1.891 & 2.788 & 417.7 & 17.3 & 418.0 & 386.7 & 467.6 & 744 \\
\hline Jan & 2.233 & 0.219 & 2.198 & 1.889 & 2.744 & 424.8 & 20.9 & 422.3 & 392.7 & 494.5 & 696 \\
\hline Feb & 2.199 & 0.223 & 2.152 & 1.877 & 2.895 & 423.2 & 22.0 & 417.9 & 392.2 & 484.6 & 658 \\
\hline Annual & 2.192 & 0.066 & 2.140 & 1.848 & 3.331 & 419.3 & 6.0 & 413.7 & 375.9 & 536.9 & \\
\hline
\end{tabular}

Table 3. Summary of $\mathrm{CH}_{4}$ and $\mathrm{CO}_{2}$ mixing ratios at Bode across four seasons from March 2013 to February 2014: seasonal mean, 1 standard deviation (SD), median, minimum (min.), and maximum (max.).

\begin{tabular}{|c|c|c|c|c|c|c|c|c|c|c|}
\hline \multirow[t]{2}{*}{ Season } & \multicolumn{5}{|c|}{$\mathrm{CH}_{4}(\mathrm{ppm})$} & \multicolumn{5}{|c|}{$\mathrm{CO}_{2}(\mathrm{ppm})$} \\
\hline & Mean & SD & Median & Min. & Max. & Mean & SD & Median & Min. & Max. \\
\hline Pre-monsoon & 2.157 & 0.230 & 2.082 & 1.848 & 3.121 & 426.2 & 25.5 & 417.0 & 378.8 & 536.9 \\
\hline Monsoon & 2.199 & 0.241 & 2.126 & 1.869 & 3.331 & 413.5 & 24.2 & 407.1 & 375.9 & 506.2 \\
\hline Post-monsoon & 2.210 & 0.200 & 2.167 & 1.879 & 2.762 & 417.3 & 23.1 & 414.1 & 381.9 & 486.7 \\
\hline Winter & 2.214 & 0.209 & 2.177 & 1.877 & 2.895 & 421.9 & 20.3 & 419.3 & 386.7 & 494.5 \\
\hline
\end{tabular}

sion sources such as open burning activities. However, the reduction in $\mathrm{CH}_{4}$ after October could be due to reduced $\mathrm{CH}_{4}$ emissions from paddy fields, which were high in AugustSeptember. $\mathrm{CO}_{2}$ remains relatively low during July-August, but it is over $420 \mathrm{ppm}$ from January to May. Seasonal variation in $\mathrm{CO}_{2}$ in Bode was similar, but the values are higher than the values observed in Shadnagar, India (Sreenivas et al., 2016).

The variations in $\mathrm{CO}$ were more distinct than $\mathrm{CH}_{4}$ and $\mathrm{CO}_{2}$ during the observation period (Fig. 3). The highest $\mathrm{CO}$ values were observed from January to April (0.71-0.91 ppm). The seasonal mean of $\mathrm{CO}$ mixing ratios at Bode were pre-monsoon $(0.60 \pm 0.36 \mathrm{ppm})$, monsoon $(0.26 \pm 0.09 \mathrm{ppm})$, post-monsoon $(0.40 \pm 0.15 \mathrm{ppm})$, and winter $(0.76 \pm 0.43 \mathrm{ppm})$. The maximum $\mathrm{CO}$ was observed in winter, unlike $\mathrm{CO}_{2}$, which was at a maximum in the pre-monsoon. The high $\mathrm{CO}$ in winter was due to the presence of strong local pollution sources (Putero et al., 2015) and shallow mixing-layer heights. The addition of regional forest fires and agro-residue burning augmented $\mathrm{CO}_{2}$ mixing ratios in the pre-monsoon. The water vapor mixing ratio showed a seasonal pattern opposite to $\mathrm{CO}$, with a maximum in the monsoon $(2.53 \%)$, a minimum in winter $(0.95 \%)$, and intermediate values of $1.56 \%$ in the pre-monsoon and $1.55 \%$ in the post-monsoon season.

There were days in August-September when the $\mathrm{CH}_{4}$ increased by more than $3 \mathrm{ppm}$ (Fig. 2). Enhancement in $\mathrm{CO}_{2}$ was also observed during the same time period. In the absence of tracer model simulations, the directionality of the advected air masses is unclear. Figure 4 shows that during these two months, $\mathrm{CO}_{2}$ mixing ratios were particularly high ( $>450 \mathrm{CO}_{2}$ and $>2.5 \mathrm{ppm} \mathrm{CH} \mathrm{CH}_{4}$ ), with the air masses coming from the east-northeast (E-NE). CO during the same period was not enhanced and did not show any particular directionality compared to $\mathrm{CH}_{4}$ and $\mathrm{CO}_{2}$ (Fig. 4c). Areas E$\mathrm{NE}$ of Bode are predominantly irrigated (rice paddies) during August-September, and sources such as brick kilns were not operational during this time period. Goroshi et al. (2011) reported that June to September is a growing season for rice paddies in South Asia, with high $\mathrm{CH}_{4}$ emissions during these months, and observed a peak in September in the atmospheric $\mathrm{CH}_{4}$ column over India. Model analysis also points to high methane emissions in September, which coincides with the growing period of rice paddies (Goroshi et al., 
Table 4. Comparison of monthly average $\mathrm{CH}_{4}$ and $\mathrm{CO}_{2}$ mixing ratios at a semi-urban and a rural site in Nepal (this study) with other urban and background sites in the region and elsewhere.

\begin{tabular}{|c|c|c|c|c|c|c|c|c|c|c|}
\hline \multirow{2}{*}{$\begin{array}{l}\text { Site } \\
\text { Setting } \\
\text { Species }\end{array}$} & \multicolumn{4}{|c|}{$\begin{array}{l}\text { Bode, Nepal } \\
\text { (Urban) }\end{array}$} & \multicolumn{2}{|c|}{$\begin{array}{l}\text { Chanban, Nepal } \\
\text { (Rural) }\end{array}$} & \multicolumn{2}{|c|}{$\begin{array}{l}\text { Mauna Loa, USA } \\
\text { (Background) }^{\mathrm{c}}\end{array}$} & \multicolumn{2}{|c|}{$\begin{array}{l}\text { Waliguan, China } \\
\text { (Background) }^{\mathrm{d}}\end{array}$} \\
\hline & $\mathrm{CO}_{2}$ & $\mathrm{CH}_{4}$ & $* \mathrm{CO}_{2}$ & $* \mathrm{CH}_{4}$ & $* \mathrm{CO}_{2}$ & $* \mathrm{CH}_{4}$ & $\mathrm{CO}_{2}$ & $\mathrm{CH}_{4}$ & $\mathrm{CO}_{2}$ & $\mathrm{CH}_{4}$ \\
\hline Unit & ppm & ppm & ppm & ppm & ppm & ppm & ppm & ppm & ppm & ppm \\
\hline Mar 2013 & 426.6 & 2.207 & & & & & 397.3 & 1.840 & 399.5 & 1.868 \\
\hline Apr & 430.3 & 2.183 & & & & & 398.4 & 1.837 & 402.8 & 1.874 \\
\hline May & 421.7 & 2.093 & & & & & 399.8 & 1.834 & 402.5 & 1.878 \\
\hline Jun & 417.9 & 2.061 & & & & & 398.6 & 1.818 & 397.4 & 1.887 \\
\hline Jul & 410.3 & 2.129 & & & & & 397.2 & 1.808 & 393.3 & 1.888 \\
\hline Aug & 409.9 & 2.274 & 411.3 & 2.281 & 403.4 & 2.050 & 395.2 & 1.819 & 392.0 & 1.893 \\
\hline Sep & 414.9 & 2.301 & 419.9 & 2.371 & 399.1 & 2.102 & 393.5 & 1.836 & 393.1 & 1.894 \\
\hline Oct & 417.0 & 2.210 & & & & & 393.7 & 1.836 & 395.6 & 1.876 \\
\hline Nov & 417.2 & 2.207 & & & & & 395.1 & 1.835 & 397.1 & 1.875 \\
\hline Dec & 417.7 & 2.206 & & & & & 396.8 & 1.845 & 398.6 & 1.880 \\
\hline Jan 2014 & 424.8 & 2.234 & & & & & 397.8 & 1.842 & 398.8 & 1.865 \\
\hline Feb & 423.2 & 2.199 & & & & & 397.9 & 1.834 & 401.1 & 1.878 \\
\hline \multicolumn{11}{|l|}{ Annual } \\
\hline Bode & 419.3 & 2.192 & & & & & & & & \\
\hline Mauna Loa & & & & & & & 396.8 & 1.832 & & \\
\hline Waliguan & & & & & & & & & 397.7 & 1.880 \\
\hline Shadnagar $(2014)^{\mathrm{a}}$ & 394.0 & & & & & & & & & \\
\hline Ahmedabad (2013-2015) & 413.0 & 1.920 & & & & & & & & \\
\hline
\end{tabular}

* The monthly values for $\mathrm{CO}_{2}$ and $\mathrm{CH}_{4}$ in 2015 and in ${ }^{\mathrm{a}}$ Sreenivas et al. (2016), ${ }^{\mathrm{b}}$ Chandra et al. (2016), ${ }^{\mathrm{c}}$ Dlugokencky et al. (2017) and NOAA (2015), ${ }^{\mathrm{d}}$ Dlugokencky et al. (2016a) and Dlugokencky et al. (2016b).

2011; Prasad et al., 2014). The $\mathrm{CH}_{4}$ mixing ratios at Bode in January $(2.233 \pm 0.219 \mathrm{ppm})$ and July $(2.129 \pm 0.168 \mathrm{ppm})$ were slightly higher than the observation in Darjeeling (January: $1.929 \pm 0.056 \mathrm{ppm}$; July: $1.924 \pm 0.065 \mathrm{ppm}$ ), a hill station in the eastern Himalayas (Ganesan et al., 2013). The higher $\mathrm{CH}_{4}$ values in January and July at Bode compared to Darjeeling could be because of the influence of local sources in addition to the shallow boundary layer in the Kathmandu Valley. Trash burning and brick kilns are two major sources from December until April in the Kathmandu Valley, while emissions from paddy fields occur during July-September. In contrast, the measurement site in Darjeeling was located at a higher altitude (2194 m a.s.l.) and was less influenced by local emissions. The measurements in Darjeeling reflected a regional contribution. There are limited local sources in Darjeeling, such as wood biomass burning, natural-gas-related emissions, and vehicular emissions (Ganesan et al., 2013).

The period between January and April had generally higher or the highest values of $\mathrm{CO}_{2}, \mathrm{CH}_{4}$, and $\mathrm{CO}$ at Bode. The measurement site was impacted mainly by local westerly-southwesterly (W-SW) and east-southeast (E$\mathrm{SE}$ ) winds. The W-SW typically has a wind speed in the range $\sim 1-6 \mathrm{~m} \mathrm{~s}^{-1}$ and was active during the late morning to afternoon period ( $\sim 11: 00$ to 17:00 NST; Supplement Figs. S2 and S3). Major cities in the valley, such as Kath- mandu metropolitan city and Lalitpur sub-metropolitan city, are W-SW of Bode (Fig. 1c). Winds from the E-SE were generally calm $\left(<1 \mathrm{~m} \mathrm{~s}^{-1}\right)$ and observed only during night and early morning hours (21:00 to 08:00 NST). The mixing ratio of all three species in the air mass from the E-SE was significantly higher than in the air mass from the WSW (Fig. 4). There are 10 biomass co-fired brick kilns and the Bhaktapur Industrial Estate located within 1-4 km E-SE from Bode (Sarkar et al., 2016). The brick kilns were only operational during January-April. Moreover, there were over 100 brick kilns operational in the Kathmandu Valley (Putero et al., 2015), which use low-grade lignite coal imported from India and biomass fuel to fire bricks in inefficient kilns (Brun, 2013).

Fresh emissions from the main city center were transported to Bode during daytime by W-SW winds, which mainly include vehicular emissions. Compared to monsoon months (June-August), air masses from the W-SW had higher values of all three species (Fig. 4) during winter and the pre-monsoon months. This may imply that in addition to vehicular emissions, there are other potential sources that were exclusively active during these dry months. Municipal trash burning is also common in the Kathmandu Valley, with a reported higher frequency from December to February (Putero et al., 2015). The frequency of the use of cap- 
(a)

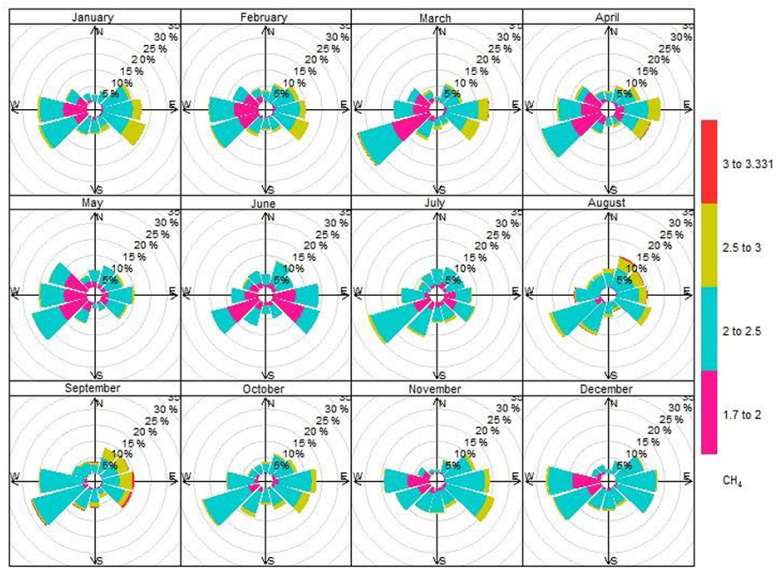

(b)
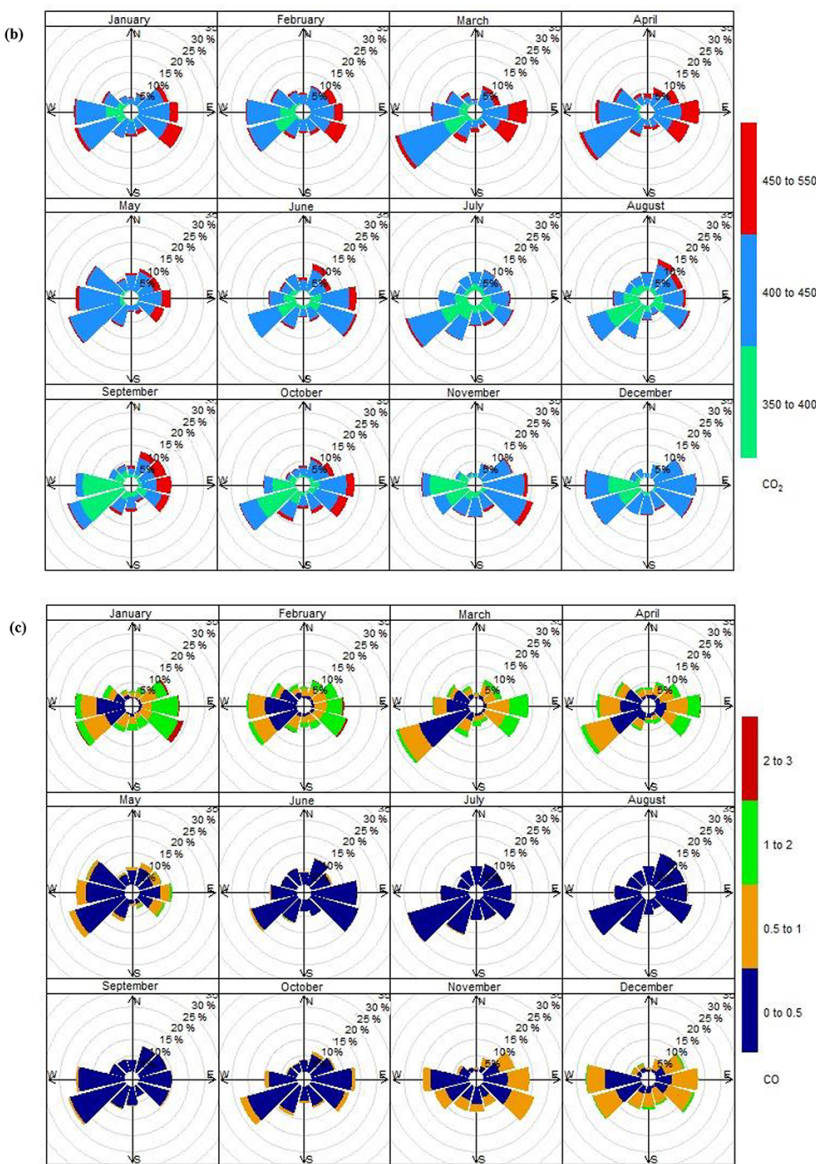

Figure 4. Relation between mixing ratios and wind direction observed at Bode in the Kathmandu Valley; (a) $\mathrm{CH}_{4}$, (b) $\mathrm{CO}_{2}$, and (c) $\mathrm{CO}$ from March 2013 to February 2014. The figure shows variations in $\mathrm{CH}_{4}, \mathrm{CO}_{2}$, and $\mathrm{CO}$ mixing ratios based on frequency counts of wind direction (in \%) as represented by the circle. The color represents the different mixing ratios of the gaseous species. The units of $\mathrm{CH}_{4}, \mathrm{CO}_{2}$, and $\mathrm{CO}$ are in ppm.

tive power generator sets is highest during the same period, which is another potential source contributing to air coming from the W-SW direction (World Bank, 2014; Putero et al., 2015).

The regional transport of pollutants into the Kathmandu Valley was reported by Putero et al. (2015). To relate the influence of synoptic circulation with the observed variability in $\mathrm{BC}$ and $\mathrm{O}_{3}$ in the Kathmandu Valley, 5-day back trajectories (of air masses arriving in the Kathmandu Valley) were computed by Putero et al. (2015) using the HYSPLIT model. These individual trajectories were initialized at $600 \mathrm{hPa}$ for the study period of 1 year and grouped into nine clusters. Of the identified clusters, the most frequently observed clusters during the study period were the regional and westerly cluster or circulation (22 and $21 \%$ ). The trajectories in the regional cluster originate within $10^{\circ} \times 10^{\circ}$ around the Kathmandu Valley, whereas the majority of trajectories in this westerly cluster originated broadly around $20-40^{\circ} \mathrm{N}, \sim 60^{\circ} \mathrm{E}$. Putero et al. (2015) found that the regional and westerly synoptic circulation were favorable for high values of $\mathrm{BC}$ and $\mathrm{O}_{3}$ in the Kathmandu Valley. Other sources of $\mathrm{CO}_{2}$ and $\mathrm{CH}_{4}$ could be vegetation fires, which were also reported in the region surrounding the Kathmandu Valley during the pre-monsoon months (Putero et al., 2015). Similarly, high pollution events in the pre-monsoon were observed at the Nepal Climate Observatory-Pyramid (NCO-P) near Mt. Everest, which have been associated with open fires along the Himalayan foothills, the northern Indo-Gangetic Plain (IGP), and other regions in the Indian subcontinent (Putero et al., 2014). MODIS-derived forest counts (Fig. 5) also indicated a high frequency of forest fires and farm fires from February to April and during the post-monsoon season. It is interesting that the monthly mean $\mathrm{CO}_{2}$ mixing ratio was at a maximum in April ( $430 \pm 27 \mathrm{ppm})$, which could be linked to the fire events. It is likely that the westerly winds $\left(>2.5-4.5 \mathrm{~m} \mathrm{~s}^{-1}\right.$ ) during the daytime (Supplement Figs. S2, S3) bring additional $\mathrm{CO}_{2}$ from vegetation fires and agroresidue burning in the southern plains of Nepal, including the IGP region (Fig. 5). Low values of $\mathrm{CO}_{2}$ and $\mathrm{CH}_{4}$ during June-July (Fig. 3) were coincident with the rainy season, and sources such as brick kiln emissions, trash burning, captive power generators, regional agricultural residue burning, and forest fires are weak or absent during these months.

\subsection{Diurnal variation}

Figure 6 shows the average seasonal diurnal patterns of the $\mathrm{CH}_{4}, \mathrm{CO}_{2}, \mathrm{CO}$, and water vapor mixing ratios observed at Bode for four seasons. All three gas species had distinct diurnal patterns in all seasons characterized by maximum values in the morning hours (peaked around 07:00-09:00), afternoon minima around 15:00-16:00, and a gradual increase through the evening until the next morning. There was no clear evening peak in $\mathrm{CH}_{4}$ and $\mathrm{CO}_{2}$ mixing ratios, whereas $\mathrm{CO}$ shows an evening peak around 20:00. The gradual increase in $\mathrm{CO}_{2}$ and $\mathrm{CH}_{4}$ in the evening in contrast to the increase until evening peak traffic hours and the later decay of 

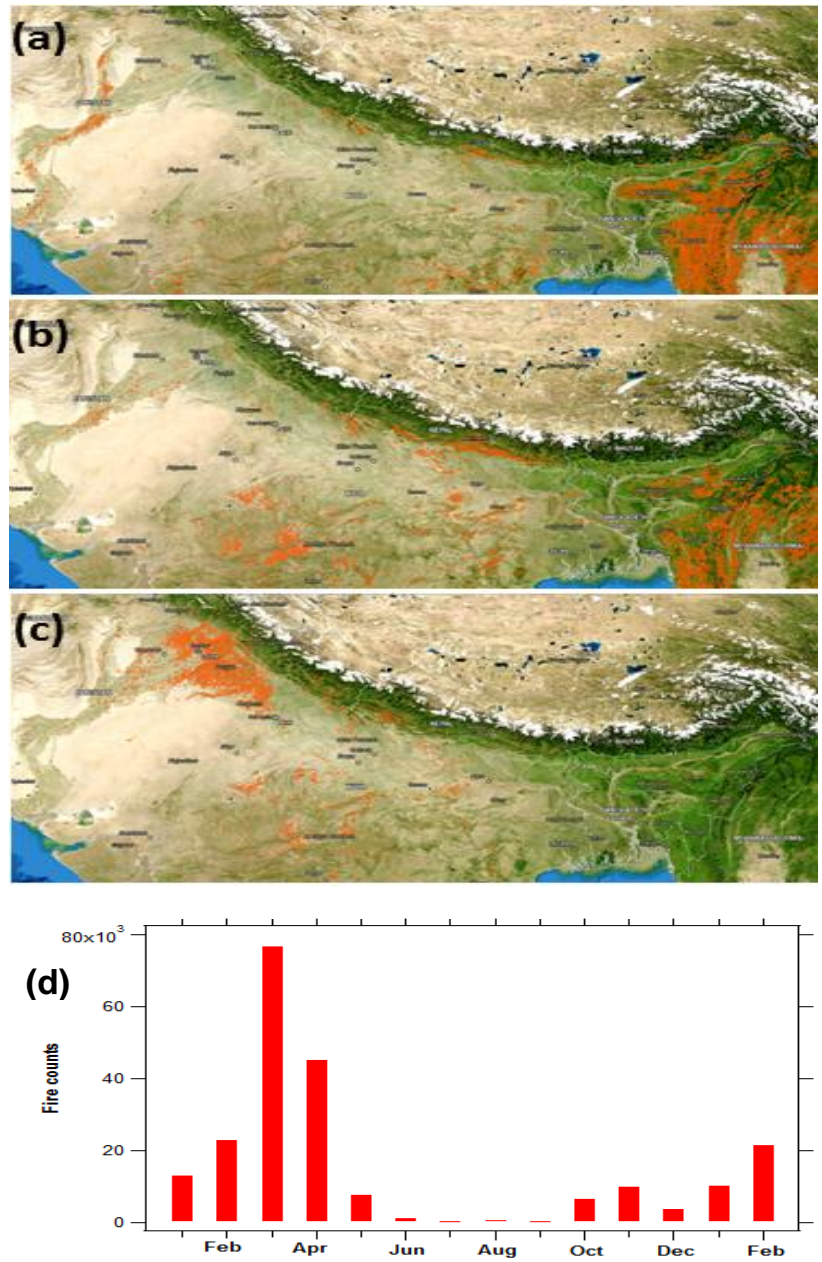

Figure 5. Satellite-detected fire counts in (a) March, (b) April, and (c) May 2013 in the broader region surrounding Nepal and (d) the total number of fire counts detected by the MODIS instrument onboard the Aqua satellite from January 2013 to February 2014. Source: https://firms.modaps.eosdis.nasa.gov/firemap/.

$\mathrm{CO}$ may be indicative of a few factors. As pointed out earlier, after the peak traffic hours, there are no particularly strong sources of $\mathrm{CO}$, especially in the monsoon and post-monsoon seasons. It is also likely that some of the $\mathrm{CO}$ is decayed due to nighttime katabatic winds, which replace polluted air masses with cold and fresh air from the nearby mountain (Panday and Prinn, 2009). As for the $\mathrm{CO}_{2}$, the biosphere respiration at night in the absence of photosynthesis can add additional $\mathrm{CO}_{2}$ to the atmosphere, which may explain part of the increase in the $\mathrm{CO}_{2}$ mixing ratio, especially in the very shallow nocturnal boundary layer. The well-defined morning and evening peaks observed in $\mathrm{CO}$ mixing ratios are associated with the peaks in traffic and residential activities. $\mathrm{CH}_{4}$ and $\mathrm{CO}_{2}$ showed pronounced peaks in the morning hours (07:0009:00) in all seasons with almost the same level of seasonal average mixing ratios. $\mathrm{CO}$ had a prominent morning peak in winter and the pre-monsoon season, but the peak was signif- icantly lower in the monsoon and post-monsoon. $\mathrm{CO}(\sim 1-$ $1.4 \mathrm{ppm}$ ) levels at around 08:00-09:00 in winter and the premonsoon were nearly 3-4 times higher than in the monsoon and post-monsoon seasons. It appears that $\mathrm{CH}_{4}$ and $\mathrm{CO}_{2}$ mixing ratios were continuously building up at night until the following morning peak in all seasons. The similar seasonal variations in $\mathrm{CH}_{4}$ and $\mathrm{CO}_{2}$ across all seasons could be due to their long-lived nature compared to $\mathrm{CO}$, the diurnal variations of which are strongly controlled by the evolution of the boundary layer. Kumar et al. (2015) also reported morning and evening peaks and an afternoon low in $\mathrm{CO}_{2}$ mixing ratios in industrial, commercial, and residential sites in Chennai in India. The authors also found high early morning $\mathrm{CO}_{2}$ mixing ratios at all sites and attributed them to temperature inversion and stable atmospheric conditions.

The daytime low $\mathrm{CH}_{4}$ and $\mathrm{CO}_{2}$ mixing ratios were due to (i) elevated mixing-layer height in the afternoon (Fig. 7), (ii) development of upslope wind circulation in the valley, and (iii) development of westerly and southwesterly winds that blow through the valley during the daytime from around 11:00 to 17:00 (Supplement Fig. S2), all of which aid in the dilution and ventilation of pollutants out of the valley (Regmi et al., 2003; Kitada and Regmi, 2003; Panday and Prinn, 2009). In addition, the daytime $\mathrm{CO}_{2}$ minimum in the summer monsoon is also associated with high photosynthetic activities in the valley and the broader surrounding region. In the nighttime and early morning, the mixing-layer height was low (only around 200-300 $\mathrm{m}$ in all seasons) and remains stable for almost $17 \mathrm{~h}$ a day. In the daytime it grows up to 800 $1200 \mathrm{~m}$ for a short time (ca. from 11:00 to 18:00; Mues et al., 2017). Therefore the emissions from various activities in the evening after 18:00 (cooking and heating, vehicles, trash burning, and brick factories in the night and morning) were trapped within the collapsing and shallow boundary layer, and hence mixing ratios were high during evening, night, and morning hours. Furthermore, plant and soil respiration also increases the $\mathrm{CO}_{2}$ mixing ratio during the night (Chandra et al., 2016). However, Ganesan et al. (2013) found a distinct diurnal cycle of $\mathrm{CH}_{4}$ mixing ratios with twin peaks in the morning (07:00-09:00) and afternoon (15:00-17:00) and a nighttime low in winter but no significant diurnal cycle in the summer of 2012 in Darjeeling, a hill station (2194 m a.s.l.) in the eastern Himalayas. The authors explained that the morning peaks could be due to the radiative heating of the ground in the morning, which breaks the inversion layer formed during the night, and as a result pollutants are ventilated from the foothills up to the site. The late afternoon peaks match the wind direction and wind speed (upslope winds) that could bring pollution from the plains to the mountains.

The diurnal variation in $\mathrm{CO}$ is also presented along with $\mathrm{CO}_{2}$ and $\mathrm{CH}_{4}$ in Fig. 6c. $\mathrm{CO}$ is an indicator of primary air pollution. Although the $\mathrm{CO}$ mixing ratio showed a distinct diurnal pattern, it was different from the diurnal patterns of $\mathrm{CO}_{2}$ and $\mathrm{CH}_{4}$. $\mathrm{CO}$ diurnal variation showed distinct morning and evening peaks, afternoon minima, and a nighttime 

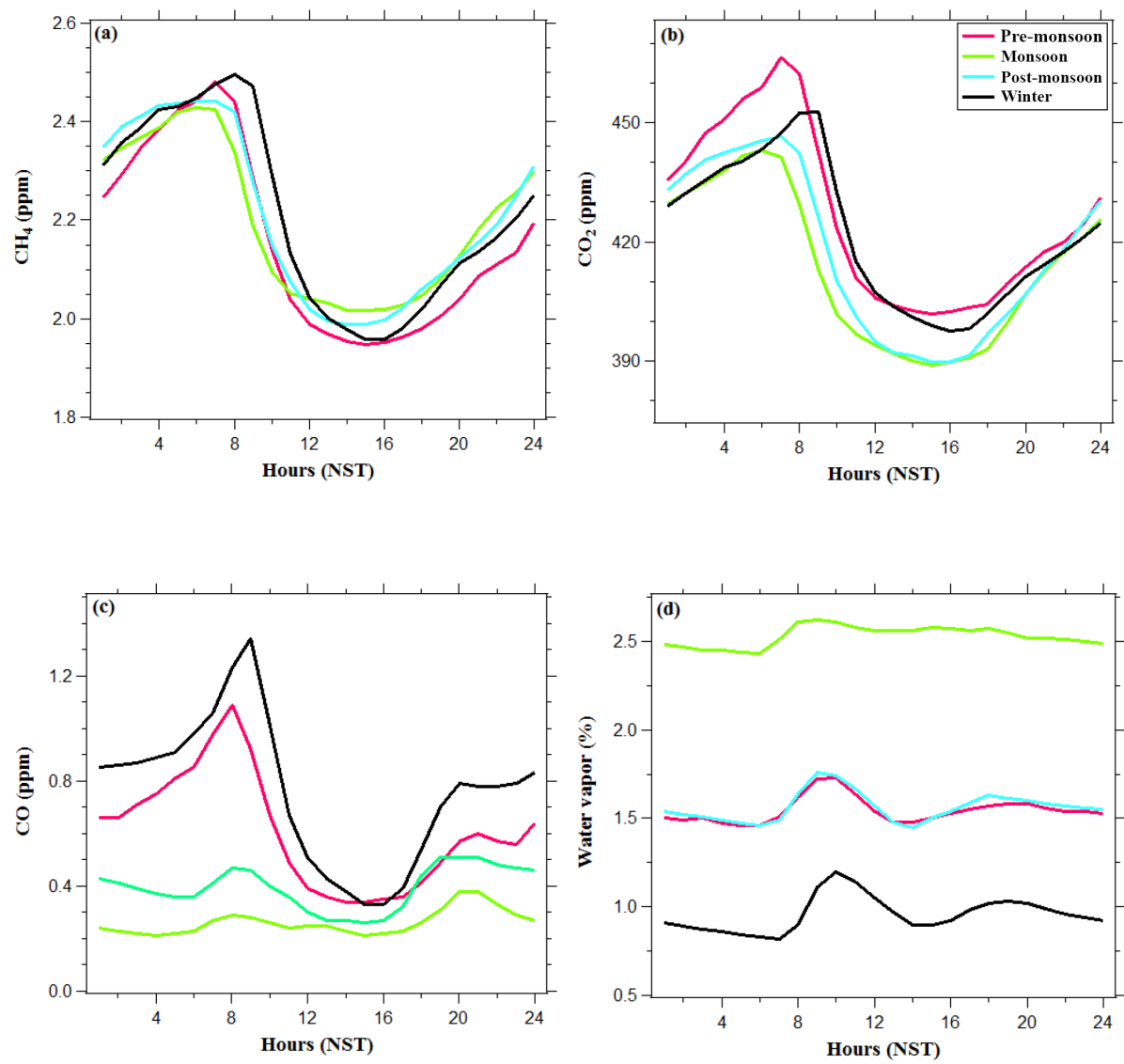

Figure 6. Diurnal variations in hourly mixing ratios in different seasons for (a) $\mathrm{CH}_{4}$, (b) $\mathrm{CO}_{2}$, (c) $\mathrm{CO}$, and (d) water vapor observed at Bode (semi-urban site) in the Kathmandu Valley from March 2013 to February 2014. Seasons are defined as pre-monsoon (March-May), monsoon (June-September), post-monsoon (October-November), and winter (December-February). The $x$ axis is in Nepal Standard Time (NST).

accumulation or decay. The nighttime accumulation of $\mathrm{CO}$ was observed only in winter and the pre-monsoon with decay or decrease in the monsoon season and post-monsoon season (Fig. 7). The lifetime of $\mathrm{CO}$ (weeks to months) is very long compared to the ventilation timescales for the valley, so the different diurnal cycles would be due to differences in nighttime emissions. While the biosphere respires at night, which may cause a notable increase in $\mathrm{CO}_{2}$ in the shallow boundary layer, most CO sources (transport sector, residential cooking) except brick kilns remain shut down or less active at night. This also explains why nighttime values of $\mathrm{CO}$ drop less in the winter and pre-monsoon than in other seasons. Furthermore, the prominent morning peaks of $\mathrm{CO}$ in the pre-monsoon and winter compared to other seasons result from nighttime accumulation, additional fresh emissions in the morning, and recirculation of the pollutants due to downslope katabatic winds (Pandey and Prinn, 2009; Panday et al., 2009). Pandey and Prinn (2009) observed nighttime accumulation and gradual decay during the winter (January 2005). The measurement site in Pandey and Prinn (2009) was near the urban core of the Kathmandu Valley and had significant influence from vehicular sources in all seasons, includ- ing the winter season. Bode lies in close proximity to brick kilns, which operate $24 \mathrm{~h}$ during the winter and pre-monsoon period. Calm southeasterly winds are observed during the nighttime and early morning (ca. 22:00-08:00) in the premonsoon and winter, which transport emissions from brick kilns to the site (Sarkar et al., 2016). Thus the gradual decay in $\mathrm{CO}$ was not observed in Bode.

The timing of the $\mathrm{CO}$ morning peak observed in this study matches the observations by Panday et al. (2009). They also found a CO morning peak at 08:00 in October 2004 and at 09:00 in January 2005. The difference could be linked to the boundary-layer stability. As the sun rises later in winter, the boundary layer stays stable for a longer time in winter, keeping mixing ratios higher in the morning hours than in other seasons with an earlier sunrise.

The morning peaks of $\mathrm{CO}_{2}$ and $\mathrm{CH}_{4}$ mixing ratios occurred around 06:00-07:00 local time in the pre-monsoon, monsoon, and post monsoon seasons, whereas in winter their peaks are delayed by $1-2 \mathrm{~h}$ in the morning: $\mathrm{CH}_{4}$ at $08: 00$ and $\mathrm{CO}_{2}$ at 09:00. $\mathrm{CO}$ showed that its morning peak was delayed compared to the $\mathrm{CO}_{2}$ and $\mathrm{CH}_{4}$ morning peaks by $1-2 \mathrm{~h}$ in the pre-monsoon, monsoon, post-monsoon (at 08:00), and win- 

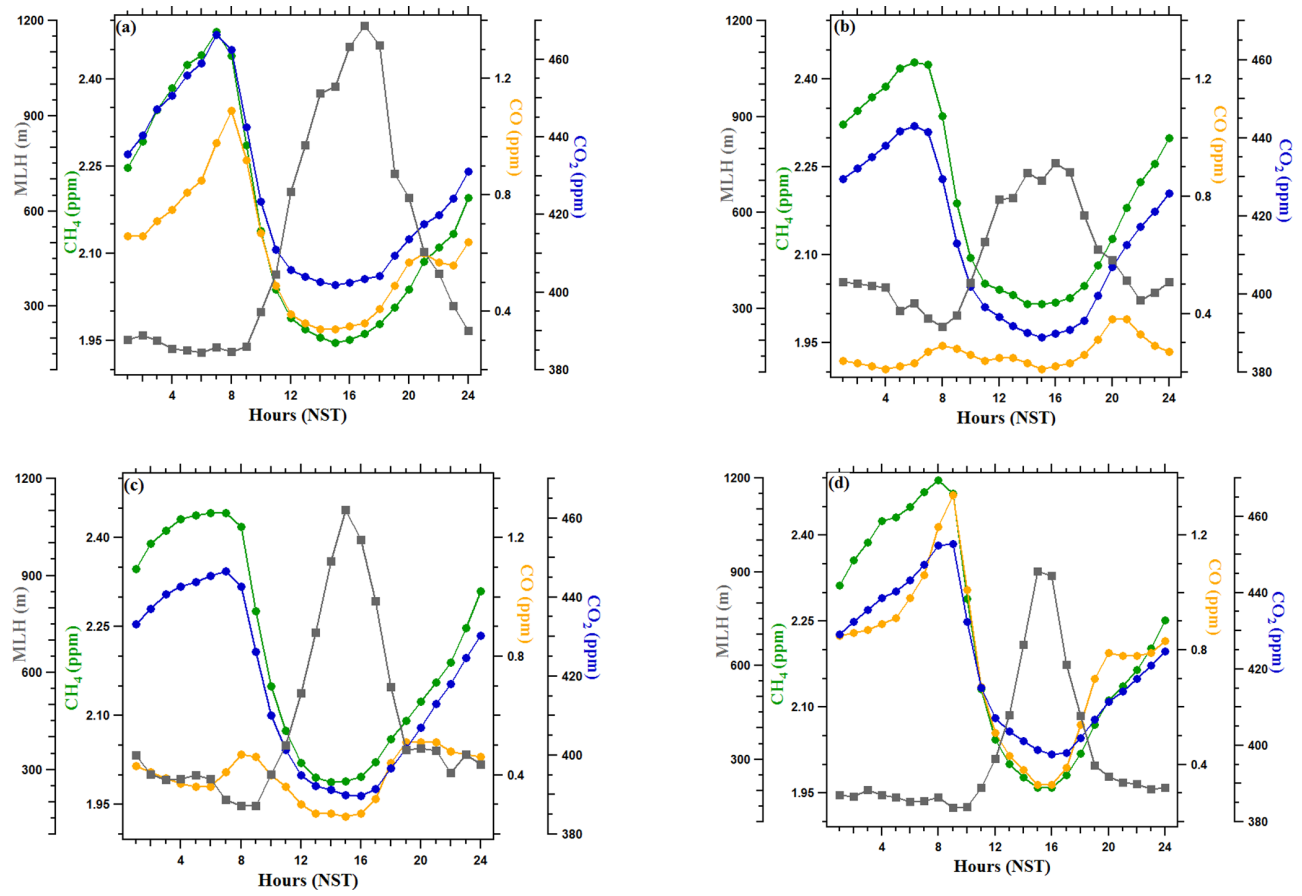

Figure 7. Diurnal variations in hourly mixing ratios of $\mathrm{CH}_{4}, \mathrm{CO}_{2}, \mathrm{CO}$, and mixing-layer height (MLH) at Bode (a semi-urban site in the Kathmandu Valley) in different seasons: (a) pre-monsoon (March-May), (b) monsoon (June-September), (c) post-monsoon (OctoberNovember), and (d) winter (December-February) from March 2013 to February 2014.

ter (at 09:00). The occurrence of morning peaks in $\mathrm{CO}_{2}$ and $\mathrm{CH}_{4}$ 1-2 $\mathrm{h}$ earlier than $\mathrm{CO}$ is interesting. This could be due to the long lifetimes and relatively smaller local sources of $\mathrm{CH}_{4}$ and $\mathrm{CO}_{2}$, as $\mathrm{CO}$ is mainly influenced by emissions from vehicles during rush hour and biomass and trash burning in the morning hours. Also, $\mathrm{CO}$ increases regardless of change in the mixing layer (collapsing or rising, Fig. 7), but $\mathrm{CO}_{2}$ and $\mathrm{CH}_{4}$ start decreasing only after the mixing-layer height starts to rise. Recently, Chandra et al. (2016) also reported that the $\mathrm{CO}_{2}$ morning peak occurred earlier than $\mathrm{CO}$ in observations in Ahmedabad, India. This was attributed to $\mathrm{CO}_{2}$ uptake by photosynthetic activities after sunrise, but CO kept increasing due to emissions from rush hour activities.

The highest daytime minimum of $\mathrm{CO}_{2}$ was observed in the pre-monsoon followed by winter (Fig. 6b). The higher daytime minimum of $\mathrm{CO}_{2}$ mixing ratios in the pre-monsoon season than in other seasons, especially winter, is interesting. The local emission sources are similar in the pre-monsoon and winter and the boundary layer is higher (in the afternoon) during the pre-monsoon $(\sim 1200 \mathrm{~m})$ than in winter $(\sim 900 \mathrm{~m}$; Mues et al., 2017). Also, the biospheric activity in the region is reported to be higher in the pre-monsoon (due to high temperatures and solar radiation) than winter (Rodda et al., 2016). Among various possible causes, the transport of $\mathrm{CO}_{2}$-rich air from outside the Kathmandu Valley has been hypothesized as a main contributing factor due to regional vegetation fires combined with westerly mesoscale to synoptic transport (Putero et al., 2015). In the monsoon and post- monsoon seasons, the minimum $\mathrm{CO}_{2}$ mixing ratio in the afternoon drops down to $390 \mathrm{ppm}$. This was close to the values observed at the regional background sites Mauna Loa and Waliguan.

\subsection{Seasonal interrelation of $\mathrm{CO}_{2}, \mathrm{CH}_{4}$, and $\mathrm{CO}$}

The Pearson's correlation coefficient $(r)$ between $\mathrm{CO}_{2}$ and $\mathrm{CO}$ was strong in winter $(0.87)$ followed by the monsoon (0.64), pre-monsoon (0.52), and post-monsoon (0.32). The higher coefficient in winter indicates common or similar sources for $\mathrm{CO}_{2}$ and $\mathrm{CO}$, and moderate values in the premonsoon and monsoon indicate the likelihood of different sources. To avoid the influence of strong diurnal variations observed in the valley, daily averages, instead of hourly, were used to calculate the correlation coefficients. The correlation coefficients between daily $\mathrm{CH}_{4}$ and $\mathrm{CO}_{2}$ for four seasons are as follows: winter $(0.80)$, post-monsoon $(0.74)$, premonsoon (0.70), and monsoon (0.22). A semi-urban measurement study in India also found a strong positive correlation between $\mathrm{CO}_{2}$ and $\mathrm{CH}_{4}$ in the pre-monsoon $(0.80)$, monsoon $(0.61)$, post-monsoon $(0.72)$, and winter $(0.8$; Sreenivas et al., 2016). It should be noted here that Sreenivas et al. (2006) used hourly average $\mathrm{CO}_{2}$ and $\mathrm{CH}_{4}$ mixing ratios. The weak monsoon correlation at Bode, which is in contrast to Sreenivas et al. (2016), may point to the influence of dominant $\mathrm{CH}_{4}$ emissions from paddy fields during the monsoon season (Goroshi et al., 2011). Daily $\mathrm{CH}_{4}$ and $\mathrm{CO}$ were also 
Table 5. Emission ratio of $\mathrm{CO} / \mathrm{CO}_{2}\left(\mathrm{ppb} \mathrm{ppm}^{-1}\right)$ derived from emission factors (mass of gas emitted per kilogram of fuel burned except for the transport sector, which is derived from grams of gases emitted per kilometer of distance traveled).

\begin{tabular}{|c|c|c|c|}
\hline Sectors & Details & $\mathrm{CO} / \mathrm{CO}_{2}$ & Reference \\
\hline \multicolumn{4}{|l|}{ 1. Residential and commercial } \\
\hline i. LPG & & 4.8 & Smith et al. (2000) \\
\hline ii. Kerosene & & 13.4 & Smith et al. (2000) \\
\hline iii. Biomass & & $52.9-98.5$ & $*$ \\
\hline \multirow[t]{2}{*}{ iv. Diesel power generators } & $<15$ years old & 5.8 & The World Bank (2014) \\
\hline & $>15$ years old & 4.5 & \\
\hline 2. Transport & & & $* *$ \\
\hline \multicolumn{4}{|l|}{ a. Diesel } \\
\hline \multirow[t]{2}{*}{ i. HCV diesel bus } & $>6000 \mathrm{cc}, 1996-2000$ & 4.9 & \\
\hline & post- 2000 and 2005 & 5.4 & \\
\hline ii. HCV diesel truck & $>6000 \mathrm{cc}$, post -2000 & 7.9 & \\
\hline \multicolumn{4}{|l|}{ b. Petrol } \\
\hline \multirow[t]{2}{*}{ i. Four-stroke motorcycle } & $<100 \mathrm{cc}, 1996-2000$ & 68 & \\
\hline & $100-200$ cc, post-2000 & 59.6 & \\
\hline ii. Passenger cars & $<1000$ cc, 1996-2000 & 42.4 & \\
\hline iii. Passenger cars & $<1000 \mathrm{cc}$, post- 2000 & 10.3 & \\
\hline \multicolumn{4}{|l|}{ 3. Brick industries } \\
\hline i. BTK fixed kiln & & 17.2 & Weyant et al. (2014) \\
\hline ii. Clamp brick kiln & & 33.7 & Stockwell et al. (2016) \\
\hline iii. Zigzag brick kiln & & 3.9 & Stockwell et al. (2016) \\
\hline \multicolumn{4}{|l|}{ 4. Open burning } \\
\hline i. Mixed garbage & & 46.9 & Stockwell et al. (2016) \\
\hline ii. Crop residue & & 51.6 & Stockwell et al. (2016) \\
\hline
\end{tabular}

weakly correlated in the monsoon (0.34) and post-monsoon (0.45). Similar to $\mathrm{CH}_{4}$ and $\mathrm{CO}_{2}$, the correlation between $\mathrm{CH}_{4}$ and $\mathrm{CO}$ was moderate to strong in the pre-monsoon $(0.76)$ and winter (0.75).

Overall, the positive and high correlations between $\mathrm{CH}_{4}$ and $\mathrm{CO}$ mixing ratios and between $\mathrm{CH}_{4}$ and $\mathrm{CO}_{2}$ mixing ratios in the pre-monsoon and winter indicate common sources, most likely combustion-related sources, such as vehicular emissions, brick kilns, and agriculture fires, or the same source regions (i.e., their transport due to regional atmospheric transport mechanisms). Weak correlation between $\mathrm{CH}_{4}$ and $\mathrm{CO}_{2}$ and between $\mathrm{CH}_{4}$ and $\mathrm{CO}$ during the monsoon season indicates that sources other than combustionrelated sources may be active, such as agriculture as a key $\mathrm{CH}_{4}$ source (Goroshi et al., 2013).

\section{5 $\mathrm{CO}$ and $\mathrm{CO}_{2}$ ratio: potential emission sources}

The ratio of the ambient mixing ratios of $\mathrm{CO}$ and $\mathrm{CO}_{2}$ was used as an indicator to help discriminate emission sources in the Kathmandu Valley. The ratio was calculated from the excess $\left(\mathrm{dCO}\right.$ and $\left.\mathrm{dCO}_{2}\right)$ relative to the background values of ambient $\mathrm{CO}$ and $\mathrm{CO}_{2}$ mixing ratios. The excess value was estimated by subtracting the base value, which was calculated as the fifth percentile of the hourly data for 1 day (Chandra et al., 2016).

Average emission ratios from the literature are shown in Table 5, and average ratios of $\mathrm{dCO} / \mathrm{dCO}_{2}$ are shown in Table 6 , disaggregated into morning hours, evening hours, and seasonal values. It must be stated that due to the large variance in the calculated ratio from this study (Table 6) and the likely variation in the estimated ratio presented in Table 5 , interpretations and conclusions about sources should be cautiously drawn and will be indicative. Higher ratios were found in the pre-monsoon (12.4) and winter (15.1) season compared to the post-monsoon (8.3) and monsoon (7.5). These seasonal differences in the $\mathrm{dCO} / \mathrm{dCO}_{2}$ ratio are depicted in Fig. 8, which shows a clear relationship with the wind direction and associated emissions with the highest values, especially for stronger westerly winds. Compared to the other three seasons, the ratio in winter was also relatively high for air masses from the east, likely due to emissions from brick kilns combined with accumulation during more stagnant meteorological conditions (Supplement Figs. S2, $\mathrm{S} 3$ ). In other seasons, emissions emanating from the north and east of Bode were characterized by a $\mathrm{dCO} / \mathrm{dCO}_{2}$ ratio below 15. Air masses from the west and south generally 
Table 6. Average (SD) of the ratio of dCO to $\mathrm{dCO}_{2}$, their geometric mean (GeoSD) over a period of $3 \mathrm{~h}$ during the (a) morning peak, (b) evening peak, and (c) seasonally (all hours) for the ambient mixing ratios of $\mathrm{CO}$ and $\mathrm{CO}_{2}$, and their lower and upper bound (LB and UB).

\begin{tabular}{|c|c|c|c|c|c|c|c|}
\hline Period & Season & Mean (SD) & Median & $N$ & Geomean (GeoSD) & LB & UB \\
\hline \multirow[t]{4}{*}{ a. Morning hours (07:00-09:00) } & Pre-monsoon & $7.6(3.1)$ & 7.8 & 249 & $11.3(1.5)$ & 5.2 & 24.8 \\
\hline & Monsoon & $2.2(1.6)$ & 1.9 & 324 & $9.9(1.9)$ & 2.7 & 36.3 \\
\hline & Post-monsoon & $3.1(1.4)$ & 2.8 & 183 & $11.1(1.5)$ & 4.7 & 26.3 \\
\hline & Winter* & $11.2(4.4)$ & 11 & 255 & $11.4(1.5)$ & 5.3 & 24.2 \\
\hline \multirow[t]{4}{*}{ b. Evening hours (19:00-21:00) } & Pre-monsoon & $15.1(9.0)$ & 12.7 & 248 & $10.5(1.7)$ & 3.5 & 31.6 \\
\hline & Monsoon & $8.0(5.2)$ & 6.3 & 323 & $10.2(1.8)$ & 3.1 & 33.5 \\
\hline & Post-monsoon & $11.5(5.6)$ & 10.6 & 182 & $11.0(1.6)$ & 4.4 & 27.6 \\
\hline & Winter & $21.6(14.1)$ & 18.2 & 254 & $10.2(1.8)$ & 3.1 & 33.6 \\
\hline \multirow[t]{4}{*}{ c. Seasonal } & Pre-monsoon & $12.2(13.3)$ & 8.8 & 1740 & $8.2(2.4)$ & 1.4 & 48.4 \\
\hline & Monsoon & $7.5(13.5)$ & 2.9 & 2176 & $5.9(3.3)$ & 0.5 & 65.6 \\
\hline & Post-monsoon & $8.3(12.4)$ & 4.4 & 1289 & $6.8(3.0)$ & 0.8 & 59.2 \\
\hline & Winter & $15.1(13.3)$ & 12.5 & 1932 & $9.2(2.1)$ & 2.0 & 41.7 \\
\hline
\end{tabular}

* The morning peak was delayed by $1 \mathrm{~h}$ in winter, and thus the 08:00-10:00 period data were used in the analysis.

have a ratio from 20 to 50 in all but the post-monsoon season when the ratio sometimes exceeds 50 . A ratio of 50 or over is normally due to very inefficient combustion sources (Westerdahl et al., 2009; Stockwell et al., 2016), such as agro-residue burning, which is common during the post-monsoon season in the Kathmandu Valley.

For interpretability of the emission ratio with sources, the ratio was classified into three categories: (i) $0-15$, (ii) $15-$ 45 , and (iii) greater than 45 . This classification was based on the observed distribution of emission ratios during the study period (Fig. 8) and a compilation of observed emission ratios typical for different sources from Nepal and India (see Table 5). An emission ratio below 15 is likely to indicate residential cooking, diesel vehicles, and captive power generation with diesel-powered generator sets (Smith et al., 2000; ARAI, 2008; World Bank, 2014). The emissions from brick kilns (FCBTK and clamp kilns, both common in the Kathmandu Valley) and inefficient, older (built before 2000) gasoline cars fall between 15 and 45 (ARAI, 2008; Weyant et al., 2014; Stockwell et al., 2016). Four-stroke motorbikes and biomass burning activities (mixed garbage, crop residue, and biomass) are among the least efficient combustion sources, with emission ratios higher than 45 (ARAI, 2008; Westerdahl et al., 2009; Stockwell et al., 2016).

Although the ratio of $\mathrm{dCO} / \mathrm{dCO}_{2}$ is a weak indicator of sources and the mean ratio has large variance (See Table 6), the conclusions drawn using Fig. 8 and the abovementioned classification are not conclusive. The estimated $\mathrm{dCO} / \mathrm{dCO}_{2}$ ratio tentatively indicates that the local plume impacting the measurement site (Bode) from the north and east could be residential and/or diesel combustion. The estimated $\mathrm{dCO} / \mathrm{dCO}_{2}$ ratio of the local plume from the south and west generally falls in the 15-45 range, which could indicate emissions from brick kilns and inefficient gasoline vehicles. Very high ratios were also estimated from the southwest dur- ing the post-monsoon season. Among other possible sources, this may indicate agro-residue open burning.

The emission inventory for $\mathrm{CO}$ identifies (aggregate for a year) residential and gasoline-related emissions from the transport sector (Sadavarte et al., 2017). The inventory is not yet temporally resolved, so no conclusion can be drawn about the sources with respect to different seasons. From the $1 \mathrm{~km} \times 1 \mathrm{~km}$ emission inventory of the Kathmandu Valley for 2011, the estimated sectoral source apportionment of CO is residential $(37 \%)$, the transport sector $(40 \%)$, and industrial $(20 \%)$. The largest fraction from the residential sector is cooking $(24 \%)$, whereas the majority of transport-sectorrelated CO in the Kathmandu Valley is from gasoline vehicles.

The $\mathrm{dCO} / \mathrm{dCO}_{2}$ ratio also changes markedly between the morning peak hours (07:00-09:00, except in the winter season when the peak occurs at 08:00-09:00) and evening peak hours (19:00-21:00 pm; Table 6). Morning and evening values were lowest $(2.2,8.0)$ during the monsoon and highest $(11.2,21.6)$ in the winter season, which points to the different emission characteristics in these two seasons. This feature is similar to Ahmedabad, India, another urban site in south Asia where the morning to evening values were lowest $(0.9 / 19.5)$ in the monsoon and highest in winter (14.3/47.2; Chandra et al., 2016). In the morning period, the ratio generally falls within a narrower range, from less than 1 to about 25 , which indicates a few dominant sources, such as cooking, diesel vehicles, and diesel generator sets (see Fig. 9). In the evening period, the range of the ratio is much wider, from less than 1 to more than 100 , especially in winter. This is partly due to the shallower boundary layer in winter, giving local $\mathrm{CO}$ emissions a chance to build up more rapidly compared to the longer-lived and well-mixed $\mathrm{CO}_{2}$, and also indicating the prevalence of additional sources, such as brick kilns and agro-residue burning. 
(a)

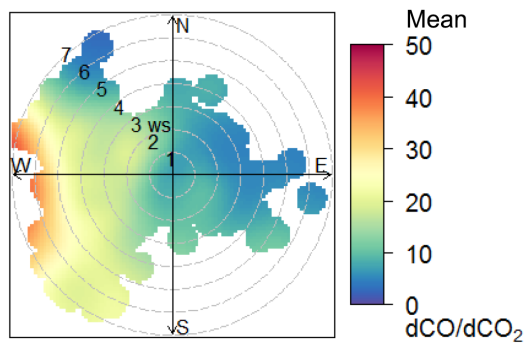

(c)

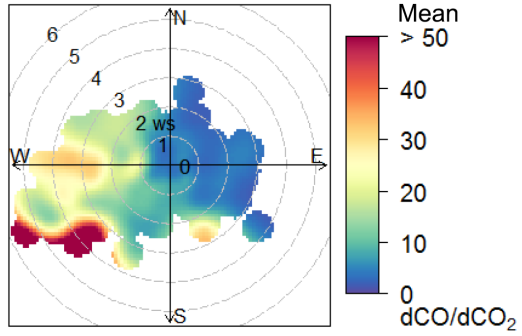

(b)

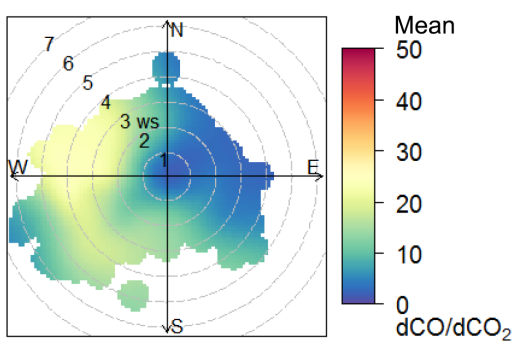

(d)

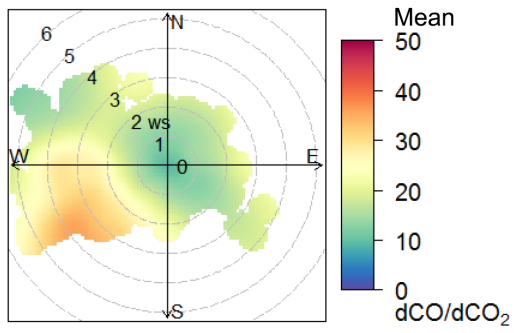

Figure 8. Seasonal polar plot of the hourly $\mathrm{dCO} / \mathrm{dCO}_{2}$ ratio based upon wind direction and wind speed: (a) pre-monsoon, (b) monsoon, (c) post-monsoon, and (d) winter seasons.

(a) Pre-monsoon

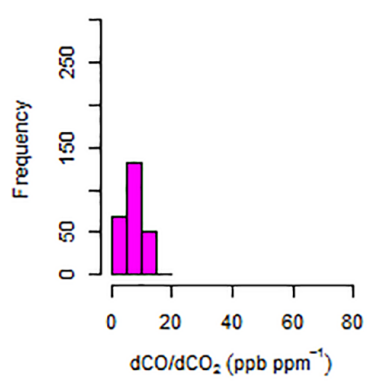

(b) Pre-monsoon

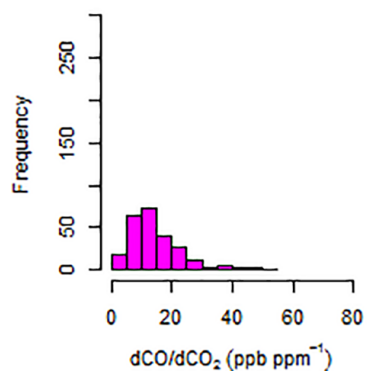

Monsoon

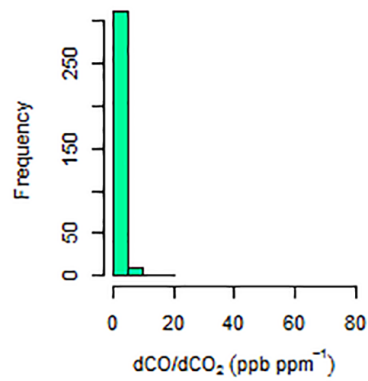

Monsoon

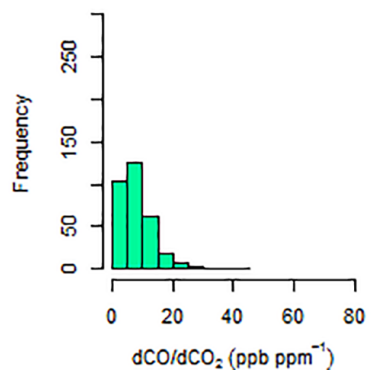

Post-monsoon

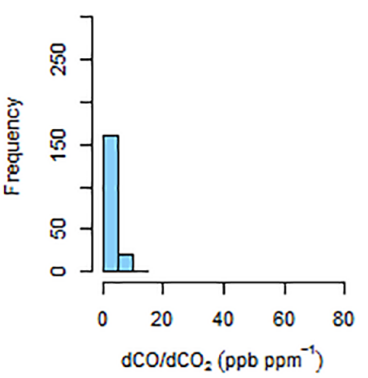

Post-monsoon

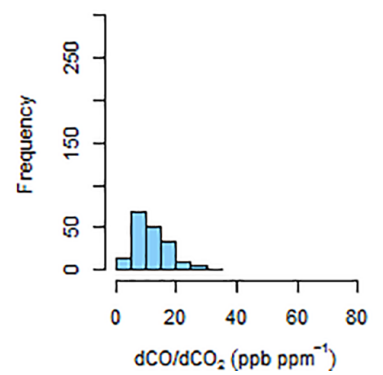

Winter

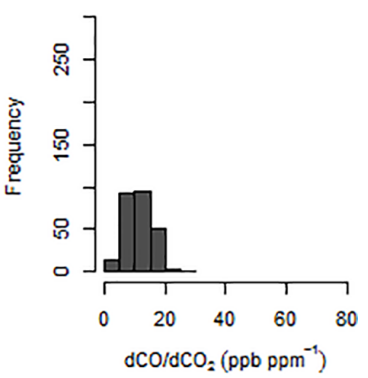

Winter

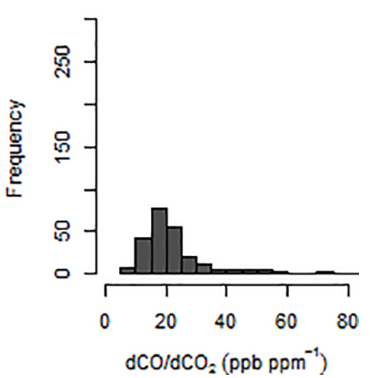

Figure 9. Seasonal frequency distribution of the hourly $\mathrm{dCO} / \mathrm{dCO}_{2}$ ratio in the (a) morning hours (07:00-09:00) in all seasons except winter (08:00-10:00) and in the (b) evening hours (19:00-21:00). 


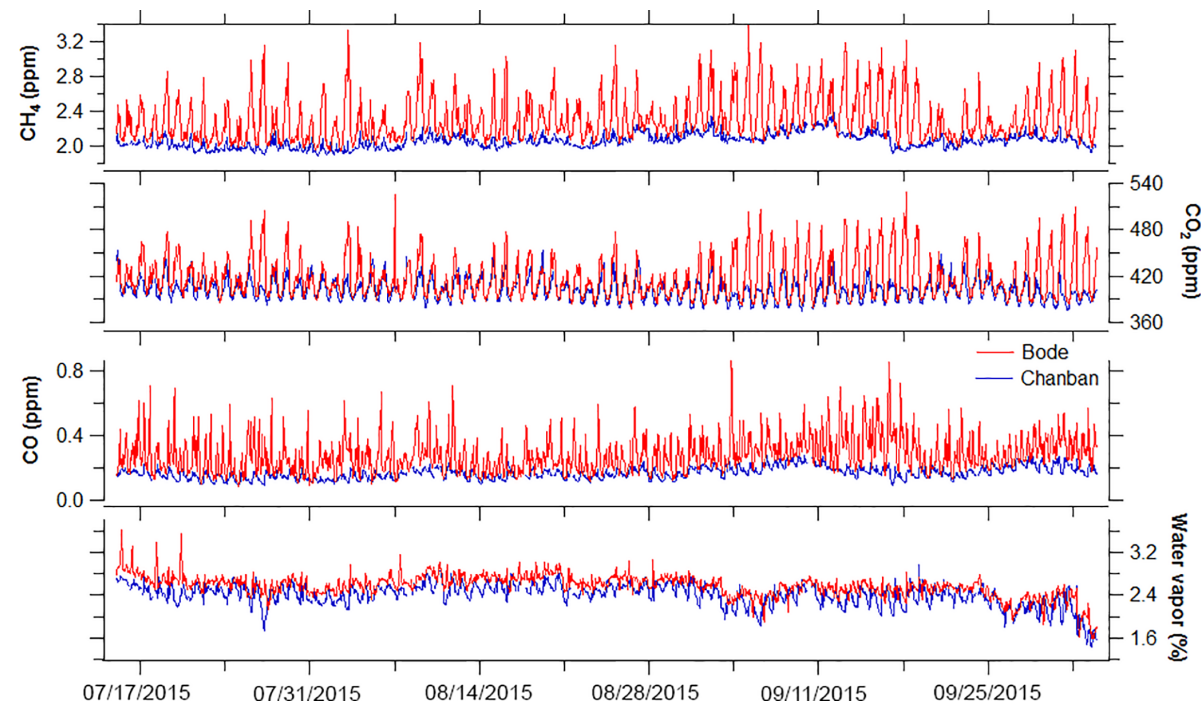

Figure 10. Comparison of hourly average mixing ratios of $\mathrm{CH}_{4}, \mathrm{CO}_{2}, \mathrm{CO}$, and water vapor observed at Bode (a semi-urban site) in the Kathmandu Valley and at Chanban (a rural background site) in the Makawanpur district $\sim 20 \mathrm{~km}$ from Kathmandu on other side of a tall ridge.

\subsection{Comparison of $\mathrm{CH}_{4}$ and $\mathrm{CO}_{2}$ at a semi-urban site (Bode) and a rural site (Chanban)}

Figure 10 shows time series of hourly average mixing ratios of $\mathrm{CH}_{4}, \mathrm{CO}_{2}, \mathrm{CO}$, and water vapor observed simultaneously at Bode and Chanban for the period of 15 July to 3 October 2015 . The hourly meteorological parameters observed at Chanban are shown in the Supplement Fig. S4. The hourly temperature ranges from 14 to $28.5^{\circ} \mathrm{C}$ during the observation period. The site experienced calm winds during the night and moderate southeasterly winds with an hourly maximum speed of up to $7.5 \mathrm{~m} \mathrm{~s}^{-1}$ during the observation period. The $\mathrm{CH}_{4}$ mixing ratios at Chanban varied from 1.880 to $2.384 \mathrm{ppm}$ and generally increased from the last week of July until early September, peaking around 11 September and then falling off towards the end of the month. CO followed a generally similar pattern, with daily average values ranging from 0.10 to $0.28 \mathrm{ppm}$. The hourly $\mathrm{CO}_{2}$ mixing ratios ranged from 375 to $453 \mathrm{ppm}$ with day-to-day variations, but there was no clear pattern as observed in trends like the $\mathrm{CH}_{4}$ and $\mathrm{CO}$ mixing ratios.

The $\mathrm{CH}_{4}, \mathrm{CO}_{2}$, and $\mathrm{CO}$ mixing ratios were higher in Bode than in Chanban (Fig. 10, Table 4), with Chanban approximately representing the baseline of the lower envelope of the Bode levels. The mean $\mathrm{CO}_{2}, \mathrm{CH}_{4}$, and $\mathrm{CO}$ mixing ratios over the entire sampling period of nearly 3 months at Bode are $3.8,12.1$, and $64 \%$ higher, respectively, than at Chanban. The difference in the $\mathrm{CO}_{2}$ mixing ratio could be due to the large uptake of $\mathrm{CO}_{2}$ in the forested area at Chanban and surrounding regions compared to Bode, where the local anthropogenic emission rate is higher with less vegetation for photosynthesis. The coincidence between the base values of
$\mathrm{CO}$ and $\mathrm{CH}_{4}$ mixing ratios at Bode and the levels observed at Chanban implies that $\mathrm{Chanban} \mathrm{CO}$ and $\mathrm{CH}_{4}$ mixing ratios are indicative of the regional background levels. A similar increase in $\mathrm{CO}$ and $\mathrm{CH}_{4}$ mixing ratios at Chanban from July to September was also observed at Bode, which may imply that the regional background levels in the broader Himalayan foothill region also influences the baseline of the daily variability in the pollutants in the Kathmandu Valley, which is consistent with Panday and Prinn (2009).

Figure 11 shows the comparison of average diurnal cycles of $\mathrm{CO}_{2}, \mathrm{CH}_{4}, \mathrm{CO}$, and water vapor mixing ratios observed at Bode and Chanban. The diurnal pattern of $\mathrm{CO}_{2}$ mixing ratios at both sites is similar but more pronounced at Bode, with a morning peak around 06:00-07:00, a daytime minimum, and a gradual increase in the evening until the next morning peak. A prominent morning peak at Bode during the monsoon season indicates the influence of local emission sources. The daytime $\mathrm{CO}_{2}$ mixing ratios are also higher at Bode than at Chanban because of local emissions and less uptake of $\mathrm{CO}_{2}$ for photosynthesis in the valley in comparison to the forested area around Chanban. Like the diurnal pattern of $\mathrm{CO}_{2}$ depends on the evolution of the mixing layer at Bode, as discussed earlier, it is expected that the mixinglayer evolution similarly influences the diurnal $\mathrm{CO}_{2}$ mixing ratios at Chanban. $\mathrm{CO}$, on the other hand, shows very different diurnal patterns at Bode and Chanban. Sharp morning and evening peaks of $\mathrm{CO}$ are seen at Bode, indicating strong local polluting sources, especially cooking and traffic in the morning and evening peak hours. Chanban, in contrast, only has a subtle morning peak and no evening peak. After the morning peak, CO sharply decreases at Bode but not at Chanban. The growth of the boundary layer after sunrise and entrainment 

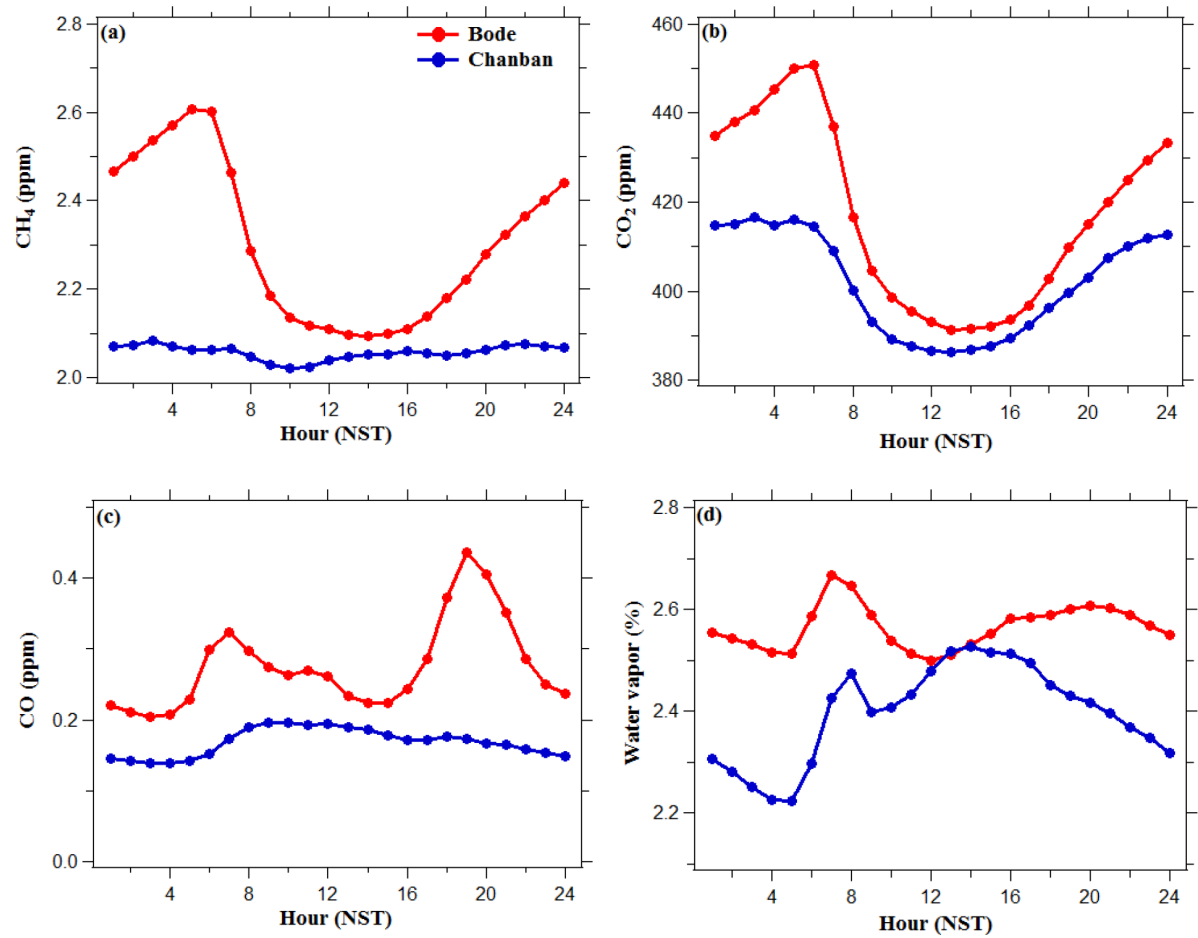

Figure 11. Diurnal variations in hourly average mixing ratios of (a) $\mathrm{CH}_{4}$, (b) $\mathrm{CO}_{2}$, (c) $\mathrm{CO}$, and (d) water vapor observed at Bode in the Kathmandu Valley and at Chanban in the Makawanpur district from 15 July to 3 October 2015.

of air from the free troposphere, with lower $\mathrm{CO}$ mixing ratios, causes $\mathrm{CO}$ to decrease sharply during the day at Bode. At Chanban, on the other hand, since the mixing ratios are already more representative of the local and regional background levels that will also be prevalent in the lower free troposphere, $\mathrm{CO}$ does not decrease notably during the daytime growth of the boundary layer as observed at Bode.

Similarly, while there is very little diurnal variation in the $\mathrm{CH}_{4}$ mixing ratios at Chanban, there is a strong diurnal cycle of $\mathrm{CH}_{4}$ at Bode, similar to $\mathrm{CO}_{2}$ there. At Chanban, the $\mathrm{CH}_{4}$ mixing ratio only shows a weak minimum at around 11:00 and a slow increase during the day until its peak around 22:00 followed by a slow decrease during the night and a more rapid decrease through the morning. The cause of this diurnal pattern at Chanban is presently unclear, but the levels could be representative of the regional background throughout the day and show only limited influences of local emissions.

\section{Conclusions}

A cavity ring-down spectrometer (G2401; Picarro, USA) was used to measure ambient $\mathrm{CO}_{2}, \mathrm{CH}_{4}, \mathrm{CO}$, and water vapor mixing ratios at a semi-urban site (Bode) in the Kathmandu Valley for 1 year. This was the first 12 months of continuous measurements of these four species in the Kathmandu Valley in the foothills of the central Himalayas. Simultaneous measurement was carried out at a rural site (Chanban) for approximately 3 months to evaluate urban-rural differences.

The measurement also provided an opportunity to establish diurnal and seasonal variation in these species in one of the biggest metropolitan cities in the foothills of the Himalayas. The annual average mixing ratios of $\mathrm{CH}_{4}$ and $\mathrm{CO}_{2}$ in Bode revealed that they were higher than the mixing ratios at background sites such as Mauna Loa, USA and Mt. Waliguan, China and higher than urban and semi-urban sites in nearby regions such as Ahmedabad and Shadnagar in India. These comparisons highlight potential sources of $\mathrm{CH}_{4}$ and $\mathrm{CO}_{2}$ in the Kathmandu Valley, such as brick kilns.

Polluted air masses were transported to the site mainly by two major local wind circulation patterns, east-southeast and west-southwest, throughout the observation period. Strong seasonality was observed with $\mathrm{CO}$ compared to $\mathrm{CO}_{2}$ and $\mathrm{CH}_{4}$. Winter and pre-monsoon high $\mathrm{CO}$ are linked to emission sources active in these seasons only and are from the east-southeast and west-southwest. Emissions from the eastsoutheast are most likely related to brick kilns (winter and pre-monsoon), which are in close proximity to Bode. Major city centers are located in the west-southwest of Bode (vehicular emissions), which impact the site all year although to a greater extent during the winter season. A winter high was also observed with $\mathrm{CO}_{2}$ and $\mathrm{CH}_{4}$, which are mostly local influences of brick kilns, trash burning, and emissions from the city center. The nighttime and early morning accu- 
mulation of pollutants in winter due to a shallow and stable mixing height (ca. $200 \mathrm{~m}$ ) also contributes to more elevated levels than in other seasons. Diurnal variation across all seasons indicates the influence of rush hour emissions related to vehicles and residential activities. The evolution of the mixing-layer height (200-1200 m) was a major factor that controls the morning-evening peak, afternoon low, and night to early morning accumulation or decay. Thus the geographical setting of the Kathmandu Valley and its associated meteorology play a key role in the dispersion and ventilation of pollutants in the Kathmandu Valley. The ratio of $\mathrm{dCO} / \mathrm{dCO}_{2}$ across different seasons and wind directions suggested that emissions from inefficient gasoline vehicles, brick kilns, residential cooking, and diesel combustion are likely to impact Bode.

The differences in mean values for urban-rural measurements at Bode and Chanban are highest for CO (64\%) compared to $\mathrm{CO}_{2}(3.8 \%)$ and $\mathrm{CH}_{4}(12 \%)$. Low values of $\mathrm{CH}_{4}$ and $\mathrm{CO}_{2}$ mixing ratios at the Chanban site could represent a regional background mixing ratio.

This study has provided valuable information on key greenhouse gases and air pollutants in the Kathmandu Valley and the surrounding regions. These observations can be useful as a ground-truthing for the evaluation of satellite measurements and climate and regional air quality models. The overall analysis presented in the paper will contribute along with other recent measurements and analyses to providing a sound scientific basis for reducing the emission of greenhouse gases and air pollutants in the Kathmandu Valley.

Data availability. Observational data collected for this study during the SusKat-ABC campaign in Nepal can be obtained by directly contacting the corresponding author of this paper at maheswar.rupakheti@iass-potsdam.de. These data will also be made public through a website maintained by the Institute for Advanced Sustainability Studies (IASS), Potsdam, Germany. Sources of other data used in the study are mentioned in the text.

\section{The Supplement related to this article is available online at https://doi.org/10.5194/acp-17-12573-2017- supplement.}

Competing interests. The authors declare that they have no conflict of interest.

Special issue statement. This article is part of the special issue "Atmospheric pollution in the Himalayan foothills: The SusKat-ABC international air pollution measurement campaign". It is not associated with a conference.
Acknowledgements. The IASS is grateful for funding from the German Federal Ministry for Education and Research (BMBF) and the Brandenburg Ministry for Science, Research and Culture (MWFK). This study was partially supported by core funds from ICIMOD contributed by the governments of Afghanistan, Australia, Austria, Bangladesh, Bhutan, China, India, Myanmar, Nepal, Norway, Pakistan, Switzerland, and the United Kingdom as well as funds provided to the ICIMOD Atmosphere Initiative by the governments of Sweden and Norway. We are grateful to Bhogendra Kathayat, Shyam Newar, Dipesh Rupakheti, Piyush Bhardwaj, Ravi Pokharel, and Pratik Singdan for their assistance during the measurement, Siva Praveen Puppala for his support in the calibration of the Picarro instrument, Pankaj Sadavarte for his help in refining Fig. 1, and Liza Manandhar and Rishi KC for the logistical support. The authors also express their appreciation to the Department of Hydrology and Meteorology (DHM), Nepal, and the Nepalese Army.

Edited by: Elizabeth Stone

Reviewed by: Dhanyalekshmi Pillai and one anonymous referee

\section{References}

Aryal, R. K., Lee, B.-K., Karki, R., Gurung, A., Baral, B., and Byeon, S.-H.: Dynamics of PM 2.5 concentrations in Kathmandu Valley, Nepal, J. Hazard. Mat., 168, 732-738, 2009.

Automotive Research Association of India (ARAI): Emission factor development for Indian vehicles, available at: http://www.cpcb. nic.in/Emission_Factors_Vehicles.pdf (last access: July 2017), 2008.

Brun, V. (Ed.): Fried earth bricks, kilns and workers in Kathmandu Valley, Himal Books, Lazimpat-Kathmandu, Nepal, 2013.

Central Bureau of Statistics (CBS): Nepal Living Standards Survey 2010/11, Statistical Report Volume 1, Central Bureau of Statistics, Government of Nepal, 2011.

Chandra, N., Lal, S., Venkataramani, S., Patra, P. K., and Sheel, V.: Temporal variations of atmospheric $\mathrm{CO}_{2}$ and $\mathrm{CO}$ at Ahmedabad in western India, Atmos. Chem. Phys., 16, 6153-6173, https://doi.org/10.5194/acp-16-6153-2016, 2016.

Chaudhari, P. R., Gajghate, D. G., Dhadse, S., Suple, S., Satapathy, D. R., and Wate, S. R.: Monitoring of environmental parameters for $\mathrm{CO} 2$ sequestration: a case study of Nagpur city, India. Environ. Monit. Assess., 135, 281, https://doi.org/10.1007/s10661007-9649-7, 2007.

Chen, H., Karion, A., Rella, C. W., Winderlich, J., Gerbig, C., Filges, A., Newberger, T., Sweeney, C., and Tans, P. P.: Accurate measurements of carbon monoxide in humid air using the cavity ring-down spectroscopy (CRDS) technique, Atmos. Meas. Tech., 6, 1031-1040, https://doi.org/10.5194/amt-6-1031-2013, 2013.

Chen, P., Kang, S., Li, C., Rupakheti, M., Yan, F., Li, Q., Ji, Z., Zhang, Q., Luo, W., and Sillanpää, M.: Characteristics and sources of polycyclic aromatic hydrocarbons in atmospheric aerosols in the Kathmandu Valley, Nepal, Sci. Total Environ., 538, 86-92, 2015.

Chen, Y. H. and Prinn, R. G.: Estimation of atmospheric methane emissions between 1996 and 2001 using a three-dimensional global chemical transport model, J. Geophys. Res.-Atmos., 111, D10307, https://doi.org/10.1029/2005JD006058, 2006. 
Conrad, R.: Soil microorganisms as controllers of atmospheric trace gases $\left(\mathrm{H}_{2}, \mathrm{CO}, \mathrm{CH}_{4}, \mathrm{OCS}, \mathrm{N}_{2} \mathrm{O}\right.$, and $\left.\mathrm{NO}\right)$, Microbiol. Rev., 60, 609-640, 1996.

Crosson, E.: A cavity ring-down analyzer for measuring atmospheric levels of methane, carbon dioxide, and water vapor, Appl. Phys. B: Lasers and Optics, 92, 403-408, 2008.

Department of Transport Management (DoTM): Annual report of Ministry of Labor and Transport Management, Nepal Government, 2015.

Dlugokencky, E. J., Lang, P. M., Crotwell, A. M., Mund, J. W., Crotwell, M. J., and Thoning, K. W.: Atmospheric Methane Dry Air Mole Fractions from the NOAA ESRL Carbon Cycle Cooperative Global Air Sampling Network, 1983-2015, Version: 2016-07-07, available at: ftp://aftp.cmdl.noaa.gov/data/ trace_gases/ch4/flask/surface/, 2016a.

Dlugokencky, E. J., Lang, P. M., Mund, J. W., Crotwell, A. M., Crotwell, M. J., and Thoning, K. W.: Atmospheric Carbon Dioxide Dry Air Mole Fractions from the NOAA ESRL Carbon Cycle Cooperative Global Air Sampling Network, 1968-2015, Version: 2016-08-30, available at: ftp://aftp.cmdl.noaa.gov/data/ trace_gases/co2/flask/surface/, 2016b.

Dlugokencky, E. J., Crotwell, A. M., Lang, P. M., and Mund, J. W.: Atmospheric Methane Dry Air Mole Fractions from quasicontinuous measurements at Mauna Loa, Hawaii, 1986-2016, Version: 2017-01-20, available at: ftp://aftp.cmdl.noaa.gov/data/ trace_gases/ch4/in-situ/surface/, 2017.

Forster, P., Ramaswamy, V., Artaxo, P., Berntsen, T., Betts, R., Fahey, D., Haywood, J., Lean, J., Lowe, D., Myhre, G., Nganga, J., Prinn, R., Raga, G., Schulz, M., and Dorland, R. V.: Changes in atmospheric constituents and in radiative forcing, in Climate Change 2007: The Physical Science Basis. Contribution of Working Group I to the Fourth Assessment Report of the Intergovernmental Panel on Climate Change, edited by: Solomon, S., Qin, D., Manning, M., Chen, Z., Marquis, M., Averyt, K. B., Tignor, M., and Miller, H. L., Cambridge University Press, Cambridge, United Kingdom and New York, NY, USA, 2007.

Fowler, A. and Hennessy, K.: Potential impacts of global warming on the frequency and magnitude of heavy precipitation, Nat. Hazards, 11, 283-303, 1995.

Fragkias, M., Lobo, J., Strumsky, D., and Seto, K. C.: Does size matter? Scaling of $\mathrm{CO}_{2}$ emissions and US urban areas, PLoS One, 8, e64727, https://doi.org/10.1371/journal.pone.0064727, 2013.

Ganesan, A. L., Chatterjee, A., Prinn, R. G., Harth, C. M., Salameh, P. K., Manning, A. J., Hall, B. D., Mühle, J., Meredith, L. K., Weiss, R. F., O'Doherty, S., and Young, D.: The variability of methane, nitrous oxide and sulfur hexafluoride in Northeast India, Atmos. Chem. Phys., 13, 10633-10644, https://doi.org/10.5194/acp-13-10633-2013, 2013.

Goroshi, S. K., Singh, R., Panigrahy, S., and Parihar, J.: Analysis of seasonal variability of vegetation and methane concentration over India using SPOT-VEGETATION and ENVISATSCIAMACHY data, J. Indian Soc. Remote, 39, 315-321, 2011.

International Centre for Integrated Mountain Development (ICIMOD): Himalayas - Water for 1.3 Billion People. ICIMOD, Lalitpur, 2009.

Intergovernmental Panel for Climate Change (IPCC): Climate Change 2013: The Physical Science Basis. Contribution of Working Group I to the Fifth Assessment Report of the Inter- governmental Panel on Climate Change, Cambridge University Press, Cambridge, United Kingdom and New York, NY, USA, 2013.

Kim, B. M., Park, J.-S., Kim, S.-W., Kim, H., Jeon, H., Cho, C., Kim, J.-H., Hong, S., Rupakheti, M., and Panday, A. K.: Source apportionment of PM 10 mass and particulate carbon in the Kathmandu Valley, Nepal, Atmos. Environ., 123, 190-199, 2015.

Kitada, T. and Regmi, R. P.: Dynamics of air pollution transport in late wintertime over Kathmandu Valley, Nepal: As revealed with numerical simulation, J. Appl. Meteorol., 42, 1770-1798, 2003.

Kumar, M. K. and Nagendra, S. S.: Characteristics of ground level $\mathrm{CO}_{2}$ concentrations over contrasting land uses in a tropical urban environment, Atmos. Environ., 115, 286-294, 2015.

Mahesh, P., Sharma, N., Dadhwal, V. K., Rao, P. V. N., Apparao, B. V., Ghosh, A. K., Mallikarjun, K., and Ali, M. M.: Impact of Land-Sea Breeze and Rainfall on CO2Variations at a Coastal Station, J. Earth Sci. Clim. Change, 5,201, https://doi.org/10.4172/2157-7617.1000201, 2014.

Marinoni, A., Cristofanelli, P., Laj, P., Duchi, R., Putero, D., Calzolari, F., Landi, T., Vuillermoz, E., Maione, M., and Bonasoni, P.: High black carbon and ozone concentrations during pollution transport in the Himalayas: Five years of continuous observations at NCO-P global GAW station, J. Environ. Sci., 25, 1618-1625, 2013.

Ministry of Environment (MoE): Status of climate change in Nepal, Kathmandu Nepal. Kathmandu, Ministry of Environment, 2011.

Ministry of Environment and Forest (MoEF): Indian Network for Climate Change Assessment: India: Greenhouse Gas Emissions 2007, Tech. rep., 2007.

Mues, A., Rupakheti, M., Münkel, C., Lauer, A., Bozem, H., Hoor, P., Butler, T., and Lawrence, M. G.: Investigation of the mixing layer height derived from ceilometer measurements in the Kathmandu Valley and implications for local air quality, Atmos. Chem. Phys., 17, 8157-8176, https://doi.org/10.5194/acp17-8157-2017, 2017.

Nepal Electricity Authority (NEA): A year in review - fiscal year - 2013/2014, available at: http://www.nea.org.np/admin/ assets/uploads/supportive_docs/AnnualReport-2014.pdf (last access: December 2016), 2014.

NOAA ESRL Global Monitoring Division (updated annually): Atmospheric Carbon Dioxide Dry Air Mole Fractions from quasi-continuous measurements at Mauna Loa, Hawaii, compiled by: Thoning, K. W., Kitzis, D. R., and Crotwell, A., National Oceanic and Atmospheric Administration (NOAA), Earth System Research Laboratory (ESRL), Global Monitoring Division (GMD): Boulder, Colorado, USA, Version 2016-8 at: https://doi.org/10.7289/V54X55RG, 2015.

Panday, A. K. and Prinn, R. G.: Diurnal cycle of air pollution in the Kathmandu Valley, Nepal: Observations, J. Geophys. Res.Atmos., 114, D09305, https://doi.org/10.1029/2008JD009777, 2009.

Panday, A. K., Prinn, R. G., and Schär, C.: Diurnal cycle of air pollution in the Kathmandu Valley, Nepal: 2. Modeling results, J. Geophys. Res.-Atmos., 114, D21308, https://doi.org/10.1029/2008JD009808, 2009.

Pandey, A., Sadavarte, P., Rao, A. B., and Venkataraman C.: Trends in multipollutant emissions from a technologylinked inventory for India: II. Residential, agricultural and 
informal industry sectors, Atmos. Environ., 99, 341-352, https://doi.org/10.1016/j.atmosenv.2014.09.080, 2014.

Patra, P. K., Niwa, Y., Schuck, T. J., Brenninkmeijer, C. A. M., Machida, T., Matsueda, H., and Sawa, Y.: Carbon balance of South Asia constrained by passenger aircraft $\mathrm{CO}_{2}$ measurements, Atmos. Chem. Phys., 11, 4163-4175, https://doi.org/10.5194/acp-11-4163-2011, 2011.

Patra, P. K., Canadell, J. G., Houghton, R. A., Piao, S. L., Oh, N.H., Ciais, P., Manjunath, K. R., Chhabra, A., Wang, T., Bhattacharya, T., Bousquet, P., Hartman, J., Ito, A., Mayorga, E., Niwa, Y., Raymond, P. A., Sarma, V. V. S. S., and Lasco, R.: The carbon budget of South Asia, Biogeosciences, 10, 513-527, https://doi.org/10.5194/bg-10-513-2013, 2013.

Picarro: Picarro G2401 $\mathrm{CO}_{2}, \mathrm{CH}_{4}, \mathrm{CO}$, Water vapor CRDS analyzer, available at: http://hpst.cz/sites/default/files/attachments/ datasheet-g2401-crds-analyzer-co2-co-ch4-h2o-air-oct15-1. pdf (last access: February 2017), 2015.

Prasad, P., Rastogi, S., and Singh, R.: Study of satellite retrieved $\mathrm{CO}_{2}$ and $\mathrm{CH}_{4}$ concentration over India, Adv. Space Res., 54, 1933-1940, 2014.

Pudasainee, D., Sapkota, B., Shrestha, M. L., Kaga, A., Kondo, A., and Inoue, Y.: Ground level ozone concentrations and its association with NOx and meteorological parameters in Kathmandu valley, Nepal, Atmos. Environ., 40, 8081-8087, 2006.

Putero, D., Landi, T., Cristofanelli, P., Marinoni, A., Laj, P., Duchi, R., Calzolari, F., Verza, G., and Bonasoni, P.: Influence of open vegetation fires on black carbon and ozone variability in the southern Himalayas (NCO-P, $5079 \mathrm{~m}$ asl), Environ. Pollut., 184, 597-604, 2014

Putero, D., Cristofanelli, P., Marinoni, A., Adhikary, B., Duchi, R., Shrestha, S. D., Verza, G. P., Landi, T. C., Calzolari, F., Busetto, M., Agrillo, G., Biancofiore, F., Di Carlo, P., Panday, A. K., Rupakheti, M., and Bonasoni, P.: Seasonal variation of ozone and black carbon observed at Paknajol, an urban site in the Kathmandu Valley, Nepal, Atmos. Chem. Phys., 15, 13957-13971, https://doi.org/10.5194/acp-15-13957-2015, 2015.

Regmi, R. P., Kitada, T., and Kurata, G.: Numerical simulation of late wintertime local flows in Kathmandu valley, Nepal: Implication for air pollution transport, J. Appl. Meteorol., 42, 389-403, 2003.

Rodda, S. R., Thumaty, K. C., Jha, C. S., and Dadhwal, V. K.: Seasonal Variations of Carbon Dioxide, Water Vapor and Energy Fluxes in Tropical Indian Mangroves, Forests, 7, 35, https://doi.org/10.3390/f7020035, 2016.

Rupakheti, M., Panday, A. K., Lawrence, M. G., Kim, S. W., Sinha, V., Kang, S. C., Naja, M., Park, J. S., Hoor, P., Holben, B., Sharma, R. K., Mues, A., Mahata, K. S., Bhardwaj, P., Sarkar, C., Rupakheti, D., Regmi, R. P., and Gustafsson, Ö.: Air pollution in the Himalayan foothills: overview of the SusKat-ABC international air pollution measurement campaign in Nepal, in preparation, 2017.

Sadavarte, P., Das, B., Shakya, K., Rupakheti, M., Bhave, P. V., Byanju, R. M., and Lawrence, M. G.: A high resolution technology-based bottom-up emissions inventory for Nepal, in preparation, 2017.

Sahu, L. K. and Lal, S.: Distributions of C 2-C 5 NMHCs and related trace gases at a tropical urban site in India, Atmos. Environ., 40, 880-891, 2006.
Sarangi, T., Naja, M., Ojha, N., Kumar, R., Lal, S., Venkataramani, S., Kumar, A., Sagar, R., and Chandola, H. C.: First simultaneous measurements of ozone, $\mathrm{CO}$ and $\mathrm{NOy}$ at a high altitude regional representative site in the central Himalayas, J. Geophys. Res., 119, 1592-1611, https://doi.org/10.1002/2013JD020631, 2014.

Sarangi, T., Naja, M., Lal, S., Venkataramani, S., Bhardwaj, P., Ojha, N., Kumar, R., and Chandola, H. C.: First observations of light non-methane hydrocarbons (C2-C5) over a high altitude site in the central Himalayas, Atmos. Environ., 125, 450-460, 2016.

Sarkar, C., Sinha, V., Kumar, V., Rupakheti, M., Panday, A., Mahata, K. S., Rupakheti, D., Kathayat, B., and Lawrence, M. G.: Overview of VOC emissions and chemistry from PTR-TOFMS measurements during the SusKat-ABC campaign: high acetaldehyde, isoprene and isocyanic acid in wintertime air of the Kathmandu Valley, Atmos. Chem. Phys., 16, 3979-4003, https://doi.org/10.5194/acp-16-3979-2016, 2016.

Schneising, O., Buchwitz, M., Burrows, J. P., Bovensmann, H., Bergamaschi, P., and Peters, W.: Three years of greenhouse gas column-averaged dry air mole fractions retrieved from satellite - Part 2: Methane, Atmos. Chem. Phys., 9, 443-465, https://doi.org/10.5194/acp-9-443-2009, 2009.

Sharma, R., Bhattarai, B., Sapkota, B., Gewali, M., and Kjeldstad, B.: Black carbon aerosols variation in Kathmandu valley, Nepal, Atmos. Environ., 63, 282-288, 2012.

Shrestha, R. M. and Rajbhandari, S.: Energy and environmental implications of carbon emission reduction targets: Case of Kathmandu Valley, Nepal, Energ. Policy, 38, 4818-4827, 2010.

Shrestha, S. R., Oanh, N. T. K., Xu, Q., Rupakheti, M., and Lawrence, M. G.: Analysis of the vehicle fleet in the Kathmandu Valley for estimation of environment and climate co-benefits of technology intrusions, Atmos. Environ., 81, 579-590, 2013.

Sinha, V., Kumar, V., and Sarkar, C.: Chemical composition of premonsoon air in the Indo-Gangetic Plain measured using a new air quality facility and PTR-MS: high surface ozone and strong influence of biomass burning, Atmos. Chem. Phys., 14, 59215941, 10.5194/acp-14-5921-2014, 2014

Smith, K. R., Uma, R., Kishore, V., Zhang, J., Joshi, V., and Khalil, M.: Greenhouse implications of household stoves: an analysis for India, Ann. Rev. Energ. Environ., 25, 741-763, 2000.

Sreenivas, G., Mahesh, P., Subin, J., Kanchana, A. L., Rao, P. V. N., and Dadhwal, V. K.: Influence of Meteorology and interrelationship with greenhouse gases $\left(\mathrm{CO}_{2}\right.$ and $\left.\mathrm{CH}_{4}\right)$ at a suburban site of India, Atmos. Chem. Phys., 16, 3953-3967, https://doi.org/10.5194/acp-16-3953-2016, 2016.

Stockwell, C. E., Christian, T. J., Goetz, J. D., Jayarathne, T., Bhave, P. V., Praveen, P. S., Adhikari, S., Maharjan, R., DeCarlo, P. F., Stone, E. A., Saikawa, E., Blake, D. R., Simpson, I. J., Yokelson, R. J., and Panday, A. K.: Nepal Ambient Monitoring and Source Testing Experiment (NAMaSTE): emissions of trace gases and light-absorbing carbon from wood and dung cooking fires, garbage and crop residue burning, brick kilns, and other sources, Atmos. Chem. Phys., 16, 11043-11081, https://doi.org/10.5194/acp-16-11043-2016, 2016.

Tan, G. and Shibasaki, R.: Global estimation of crop productivity and the impacts of global warming by GIS and EPIC integration, Ecolog. Mod., 168, https://doi.org/10.1016/S03043800(03)00146-7, 2003. 
Westerdahl, D., Wang, X., Pan, X., and Zhang, K. M.: Characterization of on-road vehicle emission factors and microenvironmental air quality in Beijing, China, Atmos. Environ., 43, 697-705, 2009.

Weyant, C., Athalye, V., Ragavan, S., Rajarathnam, U., Lalchandani, D., Maithel, S., Baum, E., and Bond, T. C.: Emissions from South Asian brick production, Environ. Sci. Tech., 48, 64776483, 2014.

World Bank: Managing Nepal's Urban Transition, available at: http://www.worldbank.org/en/news/feature/2013/04/01/ managing-nepals-urban-transition (last access: July 2017), 2013.
World Bank: Diesel power generation: inventories, black carbon emissions in Kathmandu Valley, Nepal. Washington. The World Bank: 1818H Street NW, Washington, DC 20433, USA, 2014.

WMO: The state of greenhouse gases in the atmosphere based on global observations through 2015, http://reliefweb.int/sites/reliefweb.int/files/resources/GHG_

Bulletin_12_EN_web_JN161640.pdf (last access: December 2016), 2016. 